\title{
7. AN ELECTRON MICROPROBE STUDY OF THE AMAZON FAN ${ }^{1}$
}

\author{
Futoshi Nanayama
}

\begin{abstract}
Detrital grains were examined in 38 sediment samples from Holes 931B, 936A, and 944A of Ocean Drilling Program Leg 155 on the Amazon Fan, adjacent to the South American continental margin. All samples are Quaternary in age (<360 ka). Optically, the fine sand and silt fraction consists of quartz $(70 \%$ to $80 \%)$, feldspar (8\% to $15 \%)$ and mica $(\sim 1 \%)$. The light heavy minerals form $5 \%$ to $7 \%$ of the sediment and consist of zircon, tourmaline, hornblende, clinopyroxene, orthopyroxene, staurolite, kyanite, sillimanite, chloritoid, and garnet; opaques form $2 \%$ to $5 \%$. The quartz grains are both subangular and wellrounded with iron-rich surface coatings. Thus, the sands of the Amazon Fan are quartz arenite to subarkose. The modal and chemical compositions of the Amazon Fan sands show no vertical and temporal variations throughout the sections and stratigraphic horizons.

In order to understand the provenance of the sediments, compositions of constituent mineral grains were analyzed using the electron microprobe. From this study, five mineral assemblages have been recognized that are characteristic of medium-pressure type metamorphic rocks, high-pressure type metamorphic rocks, granitic rocks, and recycled and arc-volcanic sources. Possible sources for the assemblages are Precambrian rocks of the Guiana and Brazilian Shields, the foreland region of the Andes, arc-volcanic rocks of the Andean Cordillera, and Paleozoic to Tertiary sediments of the Amazon Basin.
\end{abstract}

\section{INTRODUCTION}

Provenance studies of sandstones or sands have been used to identify the tectonic setting of many ancient basins. Most of the effective work on ancient sandstones has been carried out by Dickinson and his co-workers (Dickinson and Suczek, 1979; Dickinson, 1982; Dickinson et al., 1983), who have inferred plate-tectonic settings based on sandstone mineralogy. However, climate, topographic relief, and modification by transport are, at best, only poorly known in most ancient sandy basins, so that evaluation of their relative importance as modifiers of sand composition is uncertain. Furthermore, adding the effects of diagenesis ensures that source-rock composition is but one of several factors that control the mineralogy of ancient sandstones. Understanding correlations between the petrography and provenance of modern sands contributes to improved interpretation of ancient sandstones (Potter, 1986, 1994). Sands are present in almost every basin, including some of the very oldest, and occur in almost every sedimentary environment (with the possible exception of the abyssal plains of some deep-sea basins). This study explores the provenance of the fine sands of the Amazon Fan that were recovered during Ocean Drilling Program (ODP) Leg 155.

The Amazon Fan is the largest oceanic fan in the Atlantic Ocean and is located off northeastern Brazil, on the South American continental margin (Fig. 1). It extends $700 \mathrm{~km}$ into abyssal depths and contains sedimentary/acoustic sequences that appear to be characteristic of many large and small modern elongated or mud-rich fan systems (Stow et al., 1985; Fig. 1). The Amazon River has been the major source of terrigenous sediments to the Equatorial Atlantic since Andean uplift during the early Miocene, almost $20 \mathrm{Ma}$ (Castro et al., 1978), initiated the development of the modern Amazon Fan. The river transports $10 \%$ of the world-total of fluvial sediment and is dominated by silt and clay (Gibbs, 1967). It flows from the Andean Cordillera in the west to the Atlantic Ocean in the east (Fig. 1) and has the world's largest drainage basin. Climate in the drainage area varies

${ }^{1}$ Flood, R.D., Piper, D.J.W., Klaus, A., and Peterson, L.C. (Eds.), 1997. Proc. ODP, Sci. Results, 155: College Station, TX (Ocean Drilling Program)

${ }^{2}$ Fuel Geology Section, Fuel Resources Department, Geological Survey of Japan, Tsukuba 305, Japan. nanayama@gsj.go.jp from tropical rainforests with rainfall up to $3000 \mathrm{~mm} / \mathrm{yr}$ (Gentry and Lopez-Parodi, 1980) to relatively dry savannahs, and even to high arid zones on the east side of the Andes. Of all the world's major rivers, the Amazon is the most "tropical." Bedrock varies from Precambrian to late Tertiary. Tertiary molasse is widespread in the western lowlands of the basin, and Mesozoic and some Paleozoic rocks form much of the Andes (Castro et al., 1978).

The present high sea-level stand prevents the Amazon River sediments from crossing the shelf (Nittrouer et al., 1991), and its sediments are deposited on the Amazon Shelf in a large subaqueous delta (Kuehl et al., 1982; Nittrouer et al., 1986). During lowered glacial sea levels, the river crossed the emergent shelf and discharged sediments directly into a submarine canyon (Damuth and Kumar, 1975). The canyon crosses the continental slope and leads to large, sinuous channels with high levees that cross the upper and middle part of the Amazon Fan. The channels are perched on top of lens-shaped, aggradational turbidite overbank deposits, forming lenticular channel-levee systems. Only one channel (Amazon Channel) is now connected to the submarine canyon. Older channel segments were progressively abandoned, as repeated breaching of a channel wall (avulsion) allowed the aggrading channel to follow a new, steeper path. As the sandy lower fan is reached, levee deposits thin and channels die out.

The abandoned channel-levee systems seen in seismic sections can be grouped into large complexes-deep levees, Lower Levee Complex, Middle Levee Complex, and Upper Levee Complex (Fig. 2) - that are separated by zones of acoustically incoherent and transparent sediment interpreted as debris-flow deposits, and in some cases by hemipelagic sediments (Flood et al., 1991). Drilling of Sites 930 through 946 on the Amazon Fan has shown that major glacial to interglacial changes in sea level and climate are reflected in the architecture and lithology of turbidite deposits.

These sediments contain direct evidence of their source, as well as controlling factors such as climate and transport. Damuth and Fairbridge (1970) reported that arkosic sand grains were deposited throughout the Guiana Basin during the last glacial, suggesting an arid Amazon Basin during glacials. However, preliminary studies by R. Kowsmann (PETROBRAS, pers. comm., 1987) suggest that not all Amazon sands are arkosic, and thus, changes in sand composition may reflect temporal patterns of arid vs. humid climate within the 

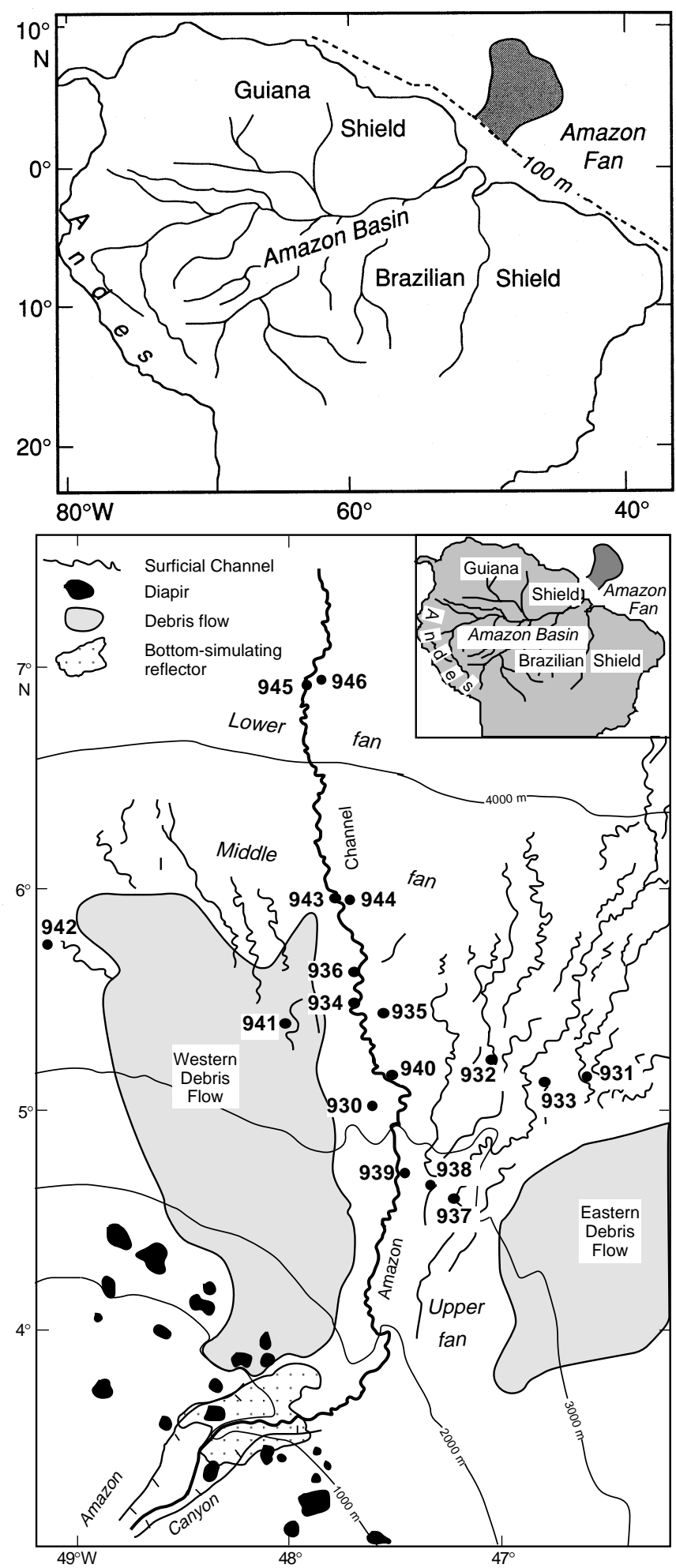

Figure 1. Top: The Amazon River drains the Andes and the Guiana and Brazilian Shields as well as the Amazon Basin. During times of lower sea level, much of the material transported by the Amazon River is deposited on the fan (from Flood, Piper, Klaus, et al., 1995). Bottom: Map of the Amazon Fan showing the location of drill sites in relation to surface channels and debris flows (from Flood, Piper, Klaus, et al., 1995; modified from Damuth et al. [1988] and Manley and Flood [1988]). The most recently active channel is the Amazon Channel.

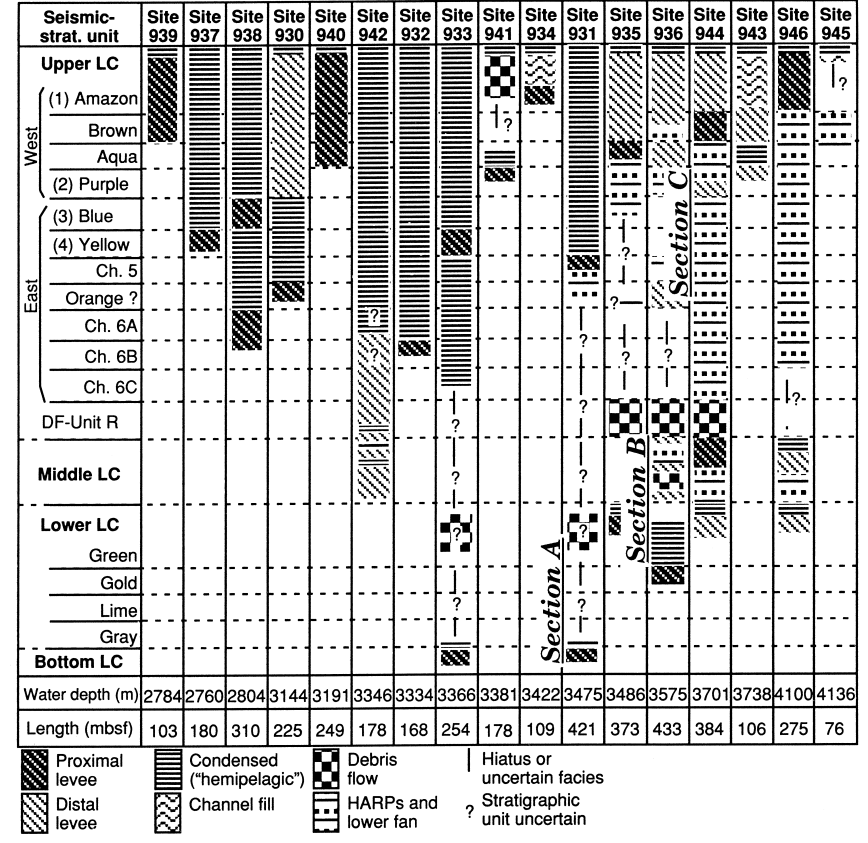

Figure 2. Summary of the relationship between facies drilled at each site and their acoustic stratigraphy. The stratigraphic positions of sections A, B, and $\mathrm{C}$ studied here are also shown (modified after Flood, Piper, Klaus, et al., 1995). Seismic-strat. unit = seismic-stratigraphic unit; $L C=$ Levee Complex; Ch. $=$ channel. Studied sections are shown for Sites 934, 935, and 936.

source area. However, there are few studies of heavy and light minerals in sediments of the Amazon Fan.

Samples for this study were obtained from Holes 931B, 936A, and 944A. In order to study the provenance of each grain species, I analyzed the modal proportions of the terrigenous minerals petrographically and the chemical compositions of detrital using an electron microprobe analyzer (EMPA).

\section{STUDIED SECTIONS}

I studied three sections (Sections A, B, and C in Fig. 2), through all levee complexes and stratigraphic horizons (Table 1). Furthermore, I studied only fine sand to silt grains from the basal part of turbidite beds (the Ta or Tb divisions of Bouma, 1962) that were not damaged due to drilling disturbance.

\section{Section A}

\section{Hole $931 B$ (Lower Levee Complex, 308.59 mbsf, to Deep Levees, $414.95 \mathrm{mbsf}$ )}

Site 931 is located on a flat terrace on the western levee of the buried Channel 5 System (Figs. 1, 2). The lower part of Unit III (257.8 to 349.25 meters below seafloor (mbsf) consists of various types of overconsolidated mud, that in places, clearly occur as clasts, some of which consist of foraminifer- and nannofossil-rich clay. Benthic foraminifers in this part of the unit are deep-water taxa such as Uvigerina. The lower part of the unit is interpreted as a mud-clast conglomerate deposited by one or more debris flows. Unit IV (349.25 to $349.46 \mathrm{mbsf}$ ) consists of a highly bioturbated, dark gray foraminifernannofossil clay with $<35 \mathrm{wt} \%$ calcium carbonate. Unit V (349.46 to 421.3 mbsf) consists of bioturbated and color-banded mud with interbedded laminae and beds of silt and very fine sand. This unit is correlated with the deep levee system. 
Table 1. Sampling list of silt/sand fraction samples for compositional studies from the Amazon Fan.

\begin{tabular}{|c|c|c|c|c|c|c|c|c|c|}
\hline Section & Sample & Levee complex & Unit & Sediment facies & Hole & $\begin{array}{l}\text { Core, section, } \\
\text { interval }(\mathrm{cm})\end{array}$ & $\begin{array}{l}\text { Depth } \\
\text { (mbsf) }\end{array}$ & Lithology & Note \\
\hline $\mathrm{C}$ & NA-1 & ULC & & Distal levee & $944 \mathrm{~A}$ & $5 \mathrm{H}-1,80$ & 33.20 & Fine sand-silt & EMPA \\
\hline $\mathrm{C}$ & NA-2 & ULC & & Proximal levee & $944 \mathrm{~A}$ & $5 \mathrm{H}-5,40$ & 38.80 & Fine sand-silt & \\
\hline $\mathrm{C}$ & NA-3 & ULC & & Proximal levee & $944 \mathrm{~A}$ & $7 \mathrm{H}-2,113$ & 54.03 & Fine sand-silt & \\
\hline $\mathrm{C}$ & NA-4 & ULC & & Proximal levee & $944 \mathrm{~A}$ & $8 \mathrm{H}-1,97$ & 61.87 & Silt turbidite and mud & \\
\hline $\mathrm{C}$ & NA-5 & ULC & & Proximal levee & $944 \mathrm{~A}$ & $9 \mathrm{H}-5,6$ & 76.46 & Silt turbidite and mud & \\
\hline $\mathrm{C}$ & NA-6 & ULC & & Proximal levee & $944 \mathrm{~A}$ & $11 \mathrm{H}-4,48$ & 94.38 & Silt turbidite and mud & \\
\hline $\mathrm{C}$ & NA-7 & ULC & & Proximal levee & $944 \mathrm{~A}$ & $13 X-5,91$ & 111.77 & Fine sand-silt & \\
\hline $\mathrm{C}$ & NA-8 & ULC & & HARPs & $944 \mathrm{~A}$ & $15 \mathrm{X}-\mathrm{CC}, 5$ & 124.44 & Fine sand-silt & EMPA \\
\hline $\mathrm{C}$ & NA-9 & ULC & & HARPs & $944 \mathrm{~A}$ & $17 X-1,56$ & 143.96 & Fine sand-silt & \\
\hline $\mathrm{C}$ & NA-10 & ULC & & HARPs & $944 \mathrm{~A}$ & $18 \mathrm{X}-\mathrm{CC}, 5$ & 153.15 & Fine sand & EMPA \\
\hline $\mathrm{C}$ & NA-11 & ULC & & Proximal levee & $944 \mathrm{~A}$ & $21 \mathrm{X}-2,17$ & 183.67 & Silt turbidite and mud & \\
\hline $\mathrm{C}$ & NA-12 & ULC & & Proximal levee & $944 \mathrm{~A}$ & $21 X-2,117$ & 184.67 & Fine sand-silt & \\
\hline $\mathrm{C}$ & NA-13 & MLC & Unit R & Debrite & $944 \mathrm{~A}$ & $23 X-6,11$ & 208.81 & Silt turbidite and mud & \\
\hline $\mathrm{C}$ & NA-14 & MLC & Unit $\mathrm{R}$ & Debrite & $944 \mathrm{~A}$ & $24 \mathrm{X}-2,148$ & 213.88 & Silt turbidite and mud & EMPA \\
\hline $\mathrm{C}$ & NA-15 & MLC & Unit R & Debrite & $944 \mathrm{~A}$ & $25 X-4,111$ & 226.11 & Silt turbidite and mud & \\
\hline $\mathrm{C}$ & NA-16 & MLC & Red & Proximal levee & $944 \mathrm{~A}$ & $30 X-6,50$ & 275.73 & Fine sand-silt & EMPA \\
\hline $\mathrm{C}$ & NA-17 & MLC & Red & Proximal levee & $944 \mathrm{~A}$ & $31 X-4,67$ & 282.67 & Fine sand & \\
\hline $\mathrm{C}$ & NA-18 & MLC & Red & Proximal levee & $944 \mathrm{~A}$ & $32 X-4,110$ & 293.07 & Fine sand & EMPA \\
\hline $\mathrm{C}$ & NA-19 & MLC & Red & Proximal levee & $944 \mathrm{~A}$ & $33 \mathrm{X}-1,109$ & 298.69 & Silt turbidite and mud & \\
\hline $\mathrm{C}$ & NA-20 & MLC & Red & HARPs & $944 \mathrm{~A}$ & $34 \mathrm{X}-1,28$ & 307.58 & Silt turbidite and mud & \\
\hline $\mathrm{C}$ & NA-21 & MLC & Red & HARPs & $944 \mathrm{~A}$ & $34 X-1,53$ & 307.83 & Fine sand-silt & \\
\hline $\mathrm{C}$ & NA-22 & MLC & Red & HARPs & $944 \mathrm{~A}$ & $38 \mathrm{X}-1,14$ & 346.04 & Silt turbidite and mud & \\
\hline $\mathrm{C}$ & NA-23 & LLC & Green & Distal levee & $944 \mathrm{~A}$ & $41 X-1,90$ & 375.40 & Silt turbidite and mud & \\
\hline $\mathrm{C}$ & NA-24 & LLC & Green & Distal levee & $944 \mathrm{~A}$ & $41 \mathrm{X}-2,25$ & 376.25 & Silt turbidite and mud & \\
\hline B & NA-25 & MLC & Red & Distal levee & $936 \mathrm{~A}$ & $42 X-1,99$ & 386.69 & Fine sand & EMPA \\
\hline $\mathrm{B}$ & NA-26 & MLC & Red & Distal levee & $936 \mathrm{~A}$ & $42 \mathrm{X}-2,18$ & 387.38 & Fine sand & EMPA \\
\hline B & NA-27 & LLC & Green & Hemiperagite & $936 \mathrm{~A}$ & $44 \mathrm{X}-1,10$ & 405.10 & Silt & EMPA \\
\hline $\mathrm{B}$ & NA-28 & LLC & Gold & Proximal levee & $936 \mathrm{~A}$ & $45 X-5,11$ & 419.95 & Silt turbidite and mud & \\
\hline B & NA-29 & LLC & Gold & Proximal levee & $936 \mathrm{~A}$ & $46 \mathrm{X}-1,28$ & 424.48 & Silt turbidite and mud & EMPA \\
\hline A & NA-30 & LLC & Green & Debrite & $931 \mathrm{~B}$ & $35 \mathrm{X}-3,88$ & 319.38 & Silt turbidite and mud & EMPA \\
\hline A & NA-31 & LLC & Green & Debrite & $931 \mathrm{~B}$ & $36 X-5,121$ & 332.31 & Silt turbidite and mud & EMPA \\
\hline A & NA-32 & LLC & Green & Debrite & $931 \mathrm{~B}$ & $36 X-5,126$ & 332.36 & Silt turbidite and mud & EMPA \\
\hline A & NA-33 & LLC & Green & Debrite & $931 \mathrm{~B}$ & $37 \mathrm{X}-2,105$ & 337.35 & Silt turbidite and mud & \\
\hline A & NA-34 & DLC & & Proximal levee & $931 \mathrm{~B}$ & $39 X-5,128$ & 361.38 & Silt turbidite and mud & EMPA \\
\hline A & NA-35 & DLC & & Proximal levee & $931 \mathrm{~B}$ & $40 X-2,64$ & 365.10 & Silt turbidite and mud & \\
\hline A & NA-36 & DLC & & Proximal levee & $931 \mathrm{~B}$ & $41 X-6,100$ & 381.90 & Silt turbidite and mud & \\
\hline A & NA-37 & DLC & & Proximal levee & $931 \mathrm{~B}$ & $42 X-3,113$ & 387.03 & Silt turbidite and mud & \\
\hline A & NA-38 & DLC & & Proximal levee & $931 \mathrm{~B}$ & $43 \mathrm{X}-7,40$ & 401.37 & Fine sand & \\
\hline
\end{tabular}

Notes: ULC $=$ Upper Levee Complex MLC $=$ Middle Levee Complex $;$ LLC $=$ Lower Levee Complex; and DLC = Deep Levee Complex. EMPA $=$ electron microprobe analyzer.

The preliminary data from Flood, Piper, Klaus, et al. (1995) indicate that the thick deep-levee sequence (Unit V) is of middle Pleistocene age. It is capped by an interglacial calcareous clay (Unit IV) that is lithologically similar to Holocene foraminifer-and nannofossil-rich clay, and possibly corresponds to isotopic Stage 7 . The lower part of the debris flow (Unit III) contains no material diagnostic of an upper slope or shelf source. The presence of deep-water benthic foraminifers suggests that it may have originated by local failure of the deep levees of an adjacent channel.

\section{Section B}

\section{Hole 936A (Middle Levee Complex, 396.69 mbsf, to Lower Levee Complex, $424.48 \mathrm{mbsf}$ )}

Site 936 is located on the western levee of the Amazon Channel (Figs. 1, 2; Flood, Piper, Klaus, et al., 1995). The lower part of Unit V (377.40 to 387.52 mbsf; Subunit VC) consists of mud with laminae and thin beds of silt and fine sand. They are interpreted as distal levee deposits. The base of the subunit is color banded, with $11 \mathrm{wt} \%$ calcium carbonate, and contains a microfossil assemblage of calcareous nannofossils, interglacial planktonic foraminifers possibly representing isotopic Stage 7, and abyssal benthic foraminifers. The lowest part of Unit V (387.52 to 405.69 mbsf; Subunit VD) is a mud-clast conglomerate interpreted as a debris-flow deposit. It contains some carbonate-rich clasts ( 22 to $32 \mathrm{wt} \%$ calcium carbonate) with microfossils. Unit VI (405.69 to $433.80 \mathrm{mbsf}$ ) corresponds to the top of the Gold Levee of the Lower Levee Complex. Subunit VIA (405.69 to 415.35 mbsf) comprises moderately bioturbated carbonate-bearing clay (at least $7 \mathrm{wt} \%$ carbonate), with a high total sulfur content similar to that seen in Holocene nannofossil-foraminifer clays and possibly representing isotopic Stage 9. The subunit passes gradually downcore into Subunit VIB (415.35 to 433.8 mbsf), comprising mud with laminae and thin beds of silt and rare fine sands.

\section{Section C}

\section{Hole 944A (Upper Levee Complex, 33.20 mbsf, to Lower Levee} Complex, $377.30 \mathrm{mbs} f$ )

Site 944 is located on the middle fan, on the eastern levee of the Amazon Channel, downfan from the Amazon-Brown avulsion (Figs. $1,2)$. The site is about $2 \mathrm{~km}$ from the channel axis and on the outside of a meander bend. Six lithologic units are recognized. Unit I ( 0 to $0.54 \mathrm{mbsf}$ ) is a Holocene, bioturbated, nannofossil-foraminifer clay, with up to $38 \mathrm{wt} \%$ carbonate. Unit II ( 0.54 to $191.60 \mathrm{mbsf})$ consists of mud with interbedded laminae and beds of silt and very fine sand. The mud has $2 \%$ to $3 \%$ carbonate content. Unit III (191.60 to 268.70 mbsf) consists of various types of mud that appear to occur as blocks and have been affected by soft-sediment deformation. Many carbonate-rich clasts are found in the upper and middle parts of the unit. This unit is interpreted as a mass-transport deposit that correlates seismically with the Unit R Debris Flow. Unit IV (268.70 to $335.40 \mathrm{mbsf}$ ) consists of mud with laminae and thin beds of silt and sand. This unit correlates seismically with the Red Channel-levee System. Unit V ( 355.40 to $357.53 \mathrm{mbsf}$ ) contains two short intervals of nannofossilforaminifer clay, with up to $17 \mathrm{wt} \%$ carbonate content, passing both uphole and downhole into nannofossil-bearing clay. Unit VI (357.53 to $384.20 \mathrm{mbsf}$ ) consists of mud with laminae and thin beds of silt. It correlates seismically with the levee of the Green Channel-levee System. Log data suggest a downhole increase in the abundance of silt.

Units II and IV correspond to levee and HARP (high-amplitude reflection packet) sediments in the Upper and Middle Levee Complexes. The Unit III mass-transport deposit is thinner and has a higher 
proportion of decimeter- to meter-sized blocks. Unit V contains two short intervals of a carbonate-rich layer above the Lower Levee Complex of interglacial origin that possibly represent isotopic Stage 9.

\section{ANALYTICAL METHODOLOGY}

All of the coarse sediments from the Amazon Fan are unconsolidated. In contrast, in the deeper part, the mud samples are poorly consolidated and weakly cemented. They were disaggregated by soaking in water and then rubbing them by hand. Clay minerals and finegrained particles were removed by washing in running tap water. The carbonate was dissolved by diluted acetic acid.

First, the coarse fractions were cemented in epoxy resin and prepared for modal analyses. Second, the samples were dried and the heavy minerals separated from the remaining fraction by mixing with methylene iodide. The specific gravity of the liquid was reduced by bromoform (s.g., 2.80) to recover composite grains and aggregates of heavy and light minerals. As all the samples studied were restricted in volume (usually less than $7 \mathrm{~cm}^{3}$ ), they were not sieved. Despite this, the sample grain sizes are generally uniform, $0.05-0.25 \mathrm{~mm}$ in size, although the micaceous minerals and light minerals are usually larger.

Using the electron microprobe analyzer (Shimazu EMPA-8705; Geological Survey of Japan, Hokkaido Branch), I analyzed chemical compositions of approximately 200 grains. Ten major elements ( $\mathrm{Si}$, $\mathrm{Ti}, \mathrm{Al}, \mathrm{Cr}, \mathrm{Fe}, \mathrm{Mn}, \mathrm{Mg}, \mathrm{Ca}, \mathrm{Na}$, and $\mathrm{K}$ ) were measured for each grain. Operating conditions were as follows: accelerating voltage, $15 \mathrm{kV}$; specimen current, $10 \mathrm{nA}$; and beam diameter, $3 \mu \mathrm{m}$.

\section{OPTICAL OBSERVATIONS OF GRAINS}

A petrographic study was made of heavy and light minerals and rock fragments derived from 38 samples from Holes 931B, 936A, and 944A. Many grains are monomineralic, but composite grains and aggregates are also common. In the latter, the major modal constituent was measured.

More than 34 minerals and four rock fragments were recognized in the samples. Grains are fresh, and this may be due to preservation under relatively cold conditions after transportation. Major minerals in the light fraction are quartz, K-feldspar, and plagioclase. The most common heavy minerals are amphibole, pyroxene, epidote-group minerals, garnet-group minerals, and mica-group minerals. Persistent accessory minerals are tourmaline, zircon, iron oxides, $\mathrm{TiO}_{2}$ polymorphs, titanite, and apatite (Table 2).

\section{Modal Compositions}

Analyzed samples from the three sections are typically unimodal, very poorly sorted silt to very fine sands (Table 1). Quartz is the primary mineral component ( $70 \%$ to $80 \%$ ) with variable amounts of mica $(\sim 1 \%)$, plagioclase and K-feldspar ( $8 \%$ to $10 \%)$, heavy minerals ( $5 \%$ to $7 \%$ ), opaque minerals ( $2 \%$ to $5 \%$ ), and minor constituents $(<1 \%)$, including rock and biogenic debris (shell fragments, diatom, planktonic, and benthic foraminifers). Round quartz grains frequently exhibit iron staining.

Modal compositions of quartz, feldspar, and rock fragments are plotted on a ternary diagram (Fig. 3) and compared with those of Amazon River sediments (Franzinelli and Potter, 1983). In terms of petrographic types defined by Pettijohn et al. (1987), the Amazon Fan sands are quartz arenites to subarkoses.

\section{Quartz}

Quartz grains are found in all of the samples and are mostly euhedral monocrystals with either straight or undulatory extinction. Both subangular and rounded grains are present; the rounded grains are frequently iron stained. Furthermore, the angular type grains are gen-
Table 2. Average sand components of the Amazon Fan sediments.

\begin{tabular}{l}
\hline Quartz (70\%-80\%; round-type and angular-type) \\
\hline Feldspar $(8 \%-15 \%):$ \\
\hline Plagioclase \\
K-feldspar (micocline + sanidine) \\
Rock fragments (5\%-10\%): \\
\hline Sedimentary rock fragments (quartzite et al.) \\
Volcanic rock fragments (volcanic glass, dacite, basalt $~$ andesite) \\
Plutonic rock fragments \\
Metamorphic rock fragments (mica schist et al.) \\
Opaque minerals (2\%-5\%): \\
\hline Ilmenite \\
Hematite (magnetite?) \\
Chromian spinel \\
Mica group ( 1\%): \\
\hline Muscovite \\
Biotite \\
Heavy minerals (5\%-7 \%): \\
\hline Clinopyroxene (augite et al.) \\
Epidote group (epidote + clinozoisite) \\
Orthopyroxene (hypersthene) \\
Hornblende (brown-type and green-type) \\
Zircon (round-type and euhedral-type) \\
Chloritoid matters \\
Garnet group (grossular + andradite + almandine + pyrope) \\
Chloritoid \\
Kyanite + sillimanite? \\
Staurolite \\
Titanite (sphene) \\
Tourmaline (round-type and euhedral-type) \\
Apatite \\
Rutile and anatase (round-type and euhedral-type) \\
\hline
\end{tabular}

erally larger than round type grains. Hence, angular type grains are derived from plutonic or metamorphic rocks with a shorter transport path, and round type grains are recycled from sedimentary rocks.

\section{Feldspar}

Feldspar occurs in all of the samples, mostly as broken grains. They are subdivided into two types. Plagioclase grains are commonly fresh, angular to subangular, and unstained. Some exhibit albite and Carlsbad-albite twins; others are altered monocrystalline grains. Kfeldspar grains are stained yellow and include orthoclase, microcline, and sanidine. These grains are either euhedral or fragments from broken pieces; they are partially altered to phyllosilicate minerals.

\section{Mica-Group Minerals and Chlorite}

Biotite, muscovite, and chlorite grains are found in all samples and vary in modal composition and grain size. They are commonly present in both the heavy and light fractions. Biotite and muscovite grains are euhedral or fibrous aggregates.

\section{Garnet-Group Minerals}

Garnet grains are found in all of the samples. The most common garnet type is pale-pink to colorless, occurring as either euhedral grains or optically anomalous broken pieces. Compositionally, the garnet is mostly almandine rich and commonly has inclusions of quartz, $\mathrm{TiO}_{2}$ polymorphs, and ilmenite. It locally forms composite grains with biotite or staurolite, and very rarely with either amphibole or pyroxenes. Grossular- and andradite-rich varieties are less common.

\section{Epidote-Group Minerals}

Epidote-group minerals are found in all of the samples. They are mostly individual crystals with subordinate amounts of composite grains and aggregates. 


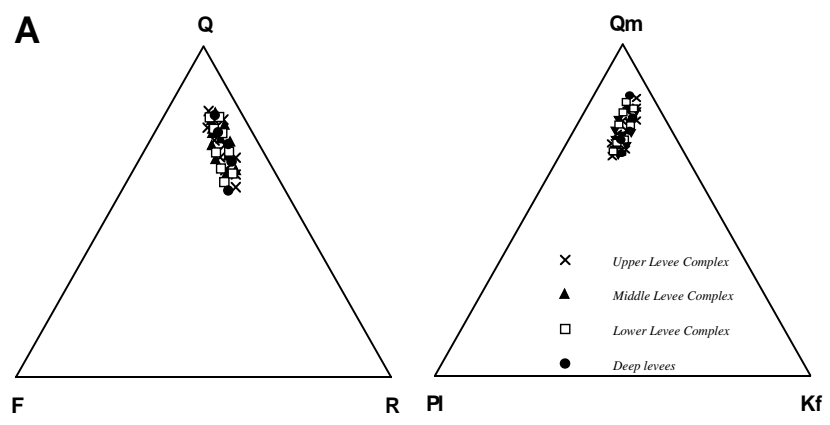

B

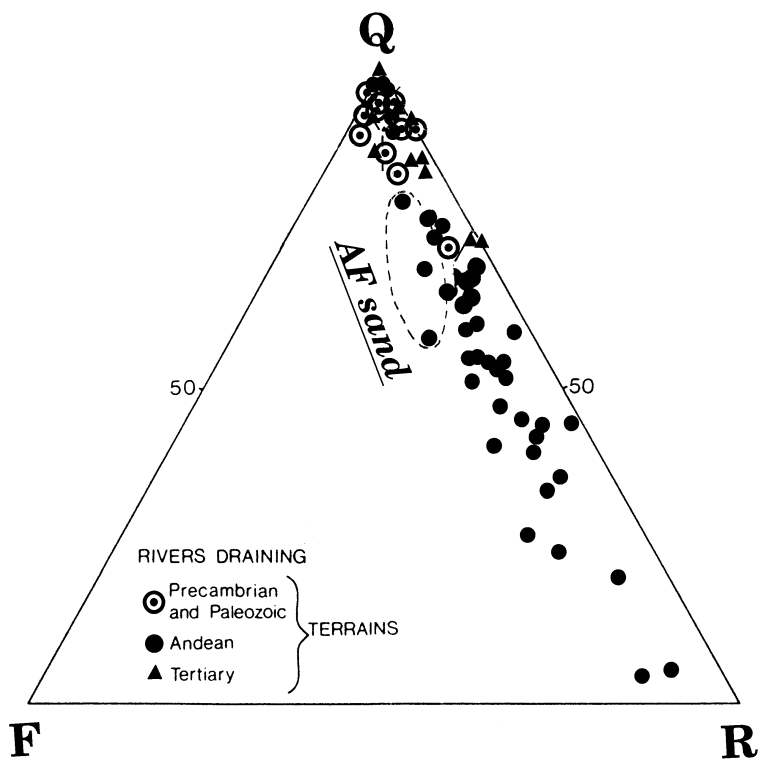

Figure 3. A. Q-F-R and Qm-Pl-Kf diagrams of sand compositions of the Amazon Fan. B. Amazon Fan sand compared with Amazon River sand (after Franzinelli and Potter, 1983). Q = quartz; F = feldspar; $\mathrm{R}=$ rock fragment; $\mathrm{Qm}=$ monocrystalline quartz $\mathrm{Pl}=$ plagioclase $; \mathrm{Kf}=\mathrm{K}$-feldspar.

\section{Hornblende}

Hornblende grains are found in all of the samples. The most common hornblende is bluish to brownish green in color and occurs as euhedral grains or broken pieces with serrated edges.

\section{Pyroxene}

Pyroxene grains are found in all of the samples. The most common clinopyroxene is pale-green augite and appears as either euhedral columnar shapes or broken pieces. The most common orthopyroxene is pale-brown hypersthene that occurs as euhedral columnar shapes or as serrated broken pieces.

\section{Staurolite}

Staurolites are found in all of the samples occur as euhedral columnar shapes or broken pieces. They exhibit colorless to golden yellow pleochroism, high refringence, and moderate birefringence.

\section{Chloritoid}

Euhedral columnar chloritoid grains are found in all of the samples. They are yellow, green, bluish green, and blue in color and display strong dispersion. Twining and zoning are frequently present. Varieties with low birefringence and anomalous interference colors can be distinguished from chlorite by higher refractive indices. Chloritoid occurs in metasediments and metabasalts that are associated with ophiolites.

\section{Zircon, Tourmaline, and Rutile}

Zircon, tourmaline, and rutile are present throughout the sequence. Each species occurs as both euhedral and round grains

\section{Iron Oxides}

There are many species of iron-rich oxides. As magnetite and hematite have variable $\mathrm{TiO}_{2}$ contents, they cannot be accurately distinguished and are treated together. Ilmenite commonly has inclusions of quartz, and is locally associated with titanite and $\mathrm{TiO}_{2}$ polymorphs. The chromian spinels are rare, but they potentially yield information about the composition of the parental rocks (Arai, 1990, 1992).

\section{Pyrite}

Pyrite is persistent in the heavy fraction. It is common in fossiliferous samples. Many pyrite grains have a well-developed framboidal texture and replace microfossils. Although there are some anhedral to subhedral pyrites of possible detrital origin, such pyrites were not counted because of the wide variety of possible sources, precluding their use in provenance determinations.

\section{Other Minerals}

Other minerals observed in the heavy fractions were kyanite, sillimanite, titanite, and apatite.

\section{Rock Fragments}

I identified four types of rock fragments: sedimentary (quartzite, shale, slate, and chert), metamorphic (mica-quartz-feldspar metasiltstone and metasandstone), plutonic (coarse aggregates of quartz, feldspar, and mica), and volcanic rock fragments (volcanic glass, dacite, andesite, and basaltic rocks).

\section{CHEMICAL COMPOSITIONS OF MINERALS}

Minerals from 14 representative samples from each levee complex of the Amazon Fan were analyzed by EMPA (Table 1).

\section{Feldspar}

Determining the chemical composition of detrital feldspar is important in studies of sand provenance and diagenesis (Trevena and Nash, 1981). Furthermore, the distribution of the albite component between coexisting alkali feldspar and plagioclase solid solutions has been used to construct a variety of geothermometers (Fuhrman and Lindsley, 1988; Fig. 4). A total of 46 grains of detrital feldspar was analyzed.

The plagioclase is of albite to andesine in most samples (Table 3). An average anorthite content of $0 \%$ to $5 \%$ (Fig. 4) indicates that the plagioclase was derived from acidic plutonic or volcanic rocks. This is supported by the low-temperature type structure in most grains, which indicates an acidic plutonic-rock origin (Fuhrman and Lindsley, 1988). K-feldspar grains generally have compositions with Or > $87 \%$, indicating a metamorphic or plutonic rock source (Fig. 4).

\section{Hornblende}

Almost all detrital amphiboles of the Amazon Fan are blue-green to brownish green hornblendes (Table 4). A total of 33 grains of detrital hornblende was analyzed. These data are highly concentrated in 
A

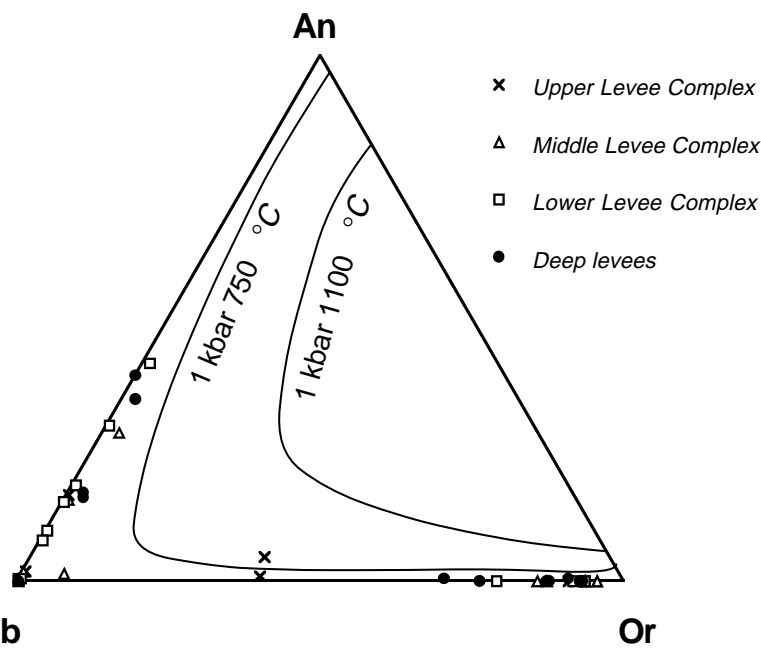

B

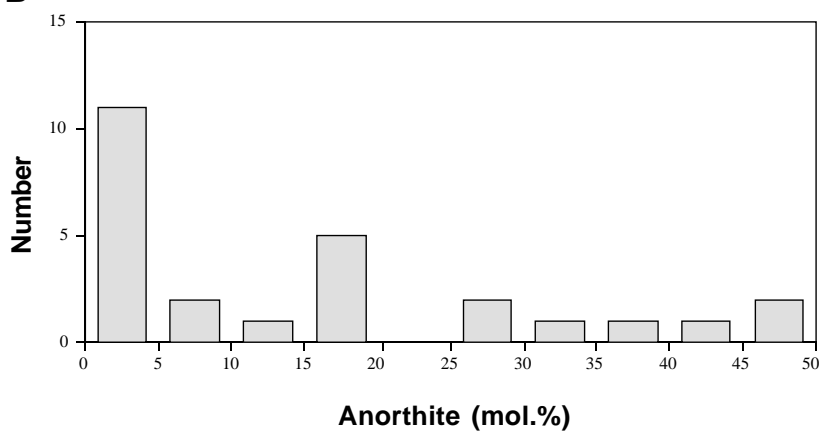

Figure 4. A. Composition of detrital feldspar (wt\%) from the Amazon Fan, with the stability fields at $750^{\circ} \mathrm{C}, 1 \mathrm{kbar}$ and at $1100^{\circ} \mathrm{C}, 1 \mathrm{kbar}$ for ternary feldspars (after Fuhrman and Lindsley, 1988). B. Variation of anorthite content $(\mathrm{mol} \%)$ in plagioclase. Vertical axis shows the number of analyses.

a Ca-Mg-Fe ${ }^{2+}+$ Mn diagram (Fig. 5), but dispersed on a $\mathrm{Na}+\mathrm{K}$ vs. $\mathrm{Al}^{\mathrm{IV}}$ diagram (Fig. 5). On a plot of $\mathrm{Mg \#}\left(\mathrm{Mg} / \mathrm{Mg}+\mathrm{Fe}^{2+}\right)$ vs. Si (Fig. 5), these data plot in the fields of magnesio-hornblende to actinolite and edenite to ferropargasite according to Leake's (1978) classification.

\section{Pyroxenes}

A total of 50 grains of detrital pyroxene was analyzed. The data are plotted on a Ca-Mg-Fe $+\mathrm{Mn}$ diagram (Fig. 6). This figure shows that orthopyroxene is typically hypersthene and that clinopyroxene is typically augite (Table 5). On the discrimination diagram of Leterrier et al. (1982), they plot in the fields typical of non-alkali basalts, orogenic basalts, and calc-alkali basalts to tholeiites (Fig. 6). Hence, the detrital pyroxenes are presumably derived from Andean volcanic rocks.

\section{Garnet}

A total of 47 grains of detrital garnet was analyzed. Variations in pyrope, almandine, and grossular in garnets of Amazon Fan sediments are shown in Figure 7 and Table 6 . The composition of the garnets from the Amazon Fan are mostly of the almandine-pyrope series, with subordinate garnets of the almandine-grossular/andradite series. The calciferous garnets from the Amazon Fan are classified into two groups. The first has $\mathrm{XCa}=\mathrm{Ca} /\left(\mathrm{Ca}+\mathrm{Mg}+\mathrm{Fe}^{2+}\right)>0.5$, which indicates a considerable proportion of the andradite component, and is presum- ably derived from calcareous rocks. The second is characterized by $0.3<\mathrm{XCa}<0.5$ and is typical of the grossular-almandine series without (or with negligible) andradite content. The latter group could have come from high-grade, intermediate to high-pressure metamorphic rocks, possibly including eclogites (Coleman et al., 1965; Fig. 7).

\section{Epidote-Group Minerals}

A total of 18 grains of detrital epidote-group minerals was analyzed. They are mostly of the epidote-clinozoisite series, with a subordinate amount of zoisite. They have a wide compositional variation, indicated by an $\mathrm{Fe}^{3+} /\left(\mathrm{Al}+\mathrm{Fe}^{3+}\right)$ range from 0.03 to 0.26 , with an average of about 0.20 (Table 7). Epidote recrystallized at low temperatures has a small compositional range, with $\mathrm{Fe}^{3+} /\left(\mathrm{Al}+\mathrm{Fe}^{3+}\right)$ around 0.33 (Dollase, 1971; Liou, 1973), and its stability field enlarges toward the aluminous end as the temperature increases (Miyashiro and Seki, 1958; Nakajima et al., 1977; Fig. 8). The epidotes from the Amazon Fan are derived from relatively high-grade metamorphic rocks such as metabasites of upper greenschist to epidote-amphibolite facies.

\section{Chloritoid}

In all, five grains of detrital chloritoid from three samples were analyzed (Table 8; Fig. 9). The Mg\# of the chloritoids are 0.08-0.29. The composition of the richest $\mathrm{Mg}$ chloritoid is far beyond the range of those so far documented from metamorphic rocks, except ultrahigh-pressure metamorphics from the western Alps (e.g., Chopin and Monie, 1984).

\section{Kyanite and Staurolite}

Kyanite and staurolites are found in all of the samples (Table 9). The $\mathrm{Fe}^{3+} /\left(\mathrm{Fe}^{3+}+\mathrm{Al}\right)$ ratios of the kyanites are $0.001-0.003$. The $\mathrm{Mg} /\left(\mathrm{Fe}^{2+}+\mathrm{Mg}\right)$ ratios of the staurolites are $0.135-0.178$.

\section{Chromian Spinel}

There are a few chromian spinels in the sediments. Chromian spinels can be classified into two types: high-Ti type $\left(\mathrm{TiO}_{2}>1 \mathrm{wt} \%\right)$ and low-Ti type $\left(\mathrm{TiO}_{2}<1 \mathrm{wt} \%\right)$. The Amazon Fan sands include only the high-Ti type (Table 10; Fig. 10). These high-Ti type spinels are derived from volcanic rocks (Arai, 1990). Furthermore, in the Cr\#-Ti diagram of Arai (1992), they plot within the field of island-arc basalts (Fig. 10). Hence, these spinels possibly originate from arc-volcanic rocks.

\section{Titanite, Ilmenite, Magnetite, and Hematite}

Most of the ilmenites in the Amazon Fan are poor in the hematite component and are represented as $\left(\mathrm{Fe}, \mathrm{Mn}\right.$, and $\mathrm{Mg}$ ) $\mathrm{Ti}_{2} \mathrm{O}_{3}$ (Table $11)$.

\section{DISCUSSION}

Approximately $80 \%$ of the sediment in the present-day Amazon River drainage system is derived from the eastern slopes of the Andes Mountains (Gibbs, 1967). The source region is subdivided into a Cenozoic volcanic province (representing $15 \%$ of the region), a Mesozoic province of sedimentary, volcanic, and plutonic rocks (55\%), and a Paleozoic/Precambrian province of primarily metamorphic rocks $(30 \%)$. Studies of the bulk chemistry of the uppermost Pleistocene fan sediments $(\sim 11 \mathrm{ka})$ suggest that weathering patterns in the source area at that time were broadly similar to those observed today (Kronberg et al., 1986; Nesbitt et al., 1990). 
Table 3. EMPA analyses of detrital feldspars from the Amazon Fan.

\begin{tabular}{|c|c|c|c|c|c|c|c|c|c|c|}
\hline \multirow[b]{3}{*}{ Mineral } & \multicolumn{10}{|c|}{ Upper Levee Complex } \\
\hline & NA-1-6 & NA-1-3 & NA-1-9 & NA-1-10 & NA-1-11 & NA-1-13 & NA-1-18 & NA-1-15 & NA-1-16 & NA-1-17 \\
\hline & K-fd & $\mathrm{pl}$ & $\mathrm{pl}$ & $\mathrm{K}-\mathrm{fd}$ & $\mathrm{pl}$ & $\mathrm{pl}$ & $\mathrm{pl}$ & $\mathrm{pl}$ & $\mathrm{K}$-fd & K-fd \\
\hline $\mathrm{SiO}_{2}$ & 64.30 & 76.85 & 64.30 & 62.11 & 58.99 & 59.29 & 51.49 & 57.44 & 61.24 & 58.67 \\
\hline $\mathrm{TiO}_{2}$ & 0.06 & 0.11 & 0.00 & 0.01 & 0.00 & 0.00 & 0.01 & 0.04 & 0.00 & 0.04 \\
\hline $\mathrm{Al}_{2} \mathrm{O}_{3}$ & 18.09 & 11.03 & 19.13 & 17.46 & 19.78 & 19.62 & 25.08 & 21.65 & 21.06 & 20.57 \\
\hline $\mathrm{Cr}_{2} \mathrm{O}_{3}$ & 0.02 & 0.02 & 0.02 & 0.00 & 0.00 & 0.00 & 0.00 & 0.02 & 0.01 & 0.00 \\
\hline $\mathrm{FeO}^{*}$ & 0.09 & 0.58 & 0.03 & 0.03 & 0.16 & 0.01 & 0.02 & 0.01 & 0.16 & 0.17 \\
\hline $\mathrm{MnO}$ & 0.04 & 0.06 & 0.08 & 0.02 & 0.00 & 0.03 & 0.00 & 0.00 & 0.00 & 0.04 \\
\hline $\mathrm{MgO}$ & 0.03 & 0.05 & 0.02 & 0.03 & 0.02 & 0.03 & 0.03 & 0.03 & 0.02 & 0.03 \\
\hline $\mathrm{CaO}$ & 0.00 & 0.47 & 0.31 & 0.02 & 0.71 & 0.15 & 5.99 & 0.08 & 0.02 & 0.01 \\
\hline $\mathrm{Na}_{2} \mathrm{O}$ & 0.93 & 3.24 & 9.16 & 0.98 & 20.79 & 20.46 & 16.76 & 23.73 & 0.94 & 1.26 \\
\hline $\mathrm{K}_{2} \mathrm{O}$ & 16.66 & 3.38 & 9.30 & 17.44 & 0.25 & 0.12 & 0.10 & 0.07 & 19.61 & 19.20 \\
\hline Total & 100.23 & 95.79 & 102.36 & 98.10 & 100.69 & 99.71 & 99.47 & 103.06 & 103.06 & 99.98 \\
\hline $\mathrm{Si}$ & 11.936 & 13.678 & 11.577 & 11.881 & 10.838 & 10.941 & 9.685 & 10.419 & 11.307 & 11.212 \\
\hline $\mathrm{Ti}$ & 0.008 & 0.014 & 0.000 & 0.002 & 0.000 & 0.000 & 0.001 & 0.005 & 0.000 & 0.006 \\
\hline $\mathrm{Al}$ & 3.958 & 2.314 & 4.060 & 3.937 & 4.283 & 4.266 & 5.559 & 4.628 & 4.583 & 4.632 \\
\hline $\mathrm{Cr}$ & 0.003 & 0.003 & 0.003 & 0.000 & 0.000 & 0.000 & 0.000 & 0.002 & 0.001 & 0.000 \\
\hline $\mathrm{Fe}^{2+}$ & 0.014 & 0.086 & 0.005 & 0.005 & 0.024 & 0.001 & 0.003 & 0.002 & 0.024 & 0.027 \\
\hline $\mathrm{Mn}$ & 0.006 & 0.009 & 0.012 & 0.004 & 0.000 & 0.005 & 0.001 & 0.000 & 0.000 & 0.007 \\
\hline $\mathrm{Mg}$ & 0.009 & 0.013 & 0.006 & 0.007 & 0.005 & 0.008 & 0.008 & 0.008 & 0.005 & 0.007 \\
\hline $\mathrm{Ca}$ & 0.000 & 0.090 & 0.060 & 0.004 & 0.139 & 0.029 & 1.208 & 0.015 & 0.004 & 0.002 \\
\hline $\mathrm{Na}$ & 0.335 & 1.118 & 3.199 & 0.363 & 7.404 & 7.321 & 6.114 & 8.345 & 0.337 & 0.466 \\
\hline $\mathrm{K}$ & 3.946 & 0.766 & 2.135 & 4.257 & 0.059 & 0.028 & 0.024 & 0.016 & 4.618 & 4.680 \\
\hline Total & 20.216 & 18.092 & 21.058 & 20.458 & 22.752 & 22.600 & 22.603 & 23.441 & 20.879 & 21.039 \\
\hline An $(\%)$ & 0.000 & 4.567 & 1.105 & 0.084 & 1.833 & 0.397 & 16.441 & 0.183 & 0.084 & 0.036 \\
\hline $\mathrm{Ab}(\%)$ & 7.836 & 56.624 & 59.311 & 7.846 & 97.393 & 99.217 & 83.229 & 99.629 & 6.793 & 9.047 \\
\hline Or $(\%)$ & 92.164 & 38.809 & 39.583 & 92.070 & 0.774 & 0.386 & 0.330 & 0.188 & 93.123 & 90.917 \\
\hline
\end{tabular}

Notes: $\mathrm{K}$-fd $=\mathrm{K}$-feldspar; $\mathrm{Pl}=$ plagioclase $; \mathrm{An}=$ anorthite $; \mathrm{Ab}=$ albite $; \mathrm{Or}=$ orthoclase $; \mathrm{FeO} *=$ total $\mathrm{Fe}$ as $\mathrm{FeO}$.

Table 3 (continued).

\begin{tabular}{|c|c|c|c|c|c|c|c|c|c|c|c|}
\hline \multirow[b]{3}{*}{ Mineral } & \multicolumn{11}{|c|}{ Middle Levee Complex } \\
\hline & NA-25-11 & NA-25-13 & NA-25-14 & NA-25-1 & NA-25-2 & NA-25-3 & NA-25-4 & NA-25-5 & NA-25-7 & NA-25-8 & NA-25-9 \\
\hline & K-fd & $\mathrm{pl}$ & K-fd & $\mathrm{pl}$ & $\mathrm{pl}$ & $\mathrm{pl}$ & $\mathrm{pl}$ & $\mathrm{K}-\mathrm{fd}$ & $\mathrm{K}-\mathrm{fd}$ & $\mathrm{K}-\mathrm{fd}$ & $\mathrm{K}-\mathrm{fd}$ \\
\hline $\mathrm{SiO}_{2}$ & 63.10 & 59.35 & 61.76 & 63.10 & 63.67 & 52.31 & 63.90 & 62.88 & 63.71 & 63.51 & 63.49 \\
\hline $\mathrm{TiO}_{2}$ & 0.00 & 0.01 & 0.03 & 0.00 & 0.01 & 0.07 & 0.01 & 0.03 & 0.00 & 0.00 & 0.01 \\
\hline $\mathrm{Al}_{2} \mathrm{O}_{3}$ & 17.46 & 22.87 & 17.82 & 17.31 & 18.25 & 23.30 & 18.48 & 17.30 & 17.40 & 17.68 & 17.63 \\
\hline $\mathrm{Cr}_{2} \mathrm{O}_{3}$ & 0.04 & 0.04 & 0.00 & 0.01 & 0.03 & 0.00 & 0.00 & 0.00 & 0.00 & 0.00 & 0.00 \\
\hline $\mathrm{FeO}^{*}$ & 0.01 & 0.05 & 0.11 & 0.13 & 0.06 & 0.50 & 0.06 & 0.05 & 0.00 & 0.05 & 0.09 \\
\hline $\mathrm{MnO}$ & 0.01 & 0.00 & 0.03 & 0.02 & 0.00 & 0.00 & 0.03 & 0.04 & 0.00 & 0.00 & 0.01 \\
\hline $\mathrm{MgO}$ & 0.04 & 0.01 & 0.02 & 0.02 & 0.00 & 0.09 & 0.00 & 0.02 & 0.00 & 0.02 & 0.02 \\
\hline $\mathrm{CaO}$ & 0.01 & 4.64 & 0.01 & 0.61 & 0.40 & 7.91 & 0.19 & 0.00 & 0.00 & 0.01 & 0.02 \\
\hline $\mathrm{Na}_{2} \mathrm{O}$ & 0.53 & 14.05 & 1.59 & 20.26 & 17.70 & 10.62 & 18.77 & 0.53 & 0.77 & 0.68 & 1.85 \\
\hline $\mathrm{K}_{2} \mathrm{O}$ & 17.87 & 0.28 & 17.03 & 0.16 & 2.17 & 0.61 & 0.05 & 17.54 & 17.32 & 15.57 & 16.83 \\
\hline Total & 99.07 & 101.30 & 98.39 & 101.60 & 102.29 & 95.40 & 101.48 & 98.38 & 99.21 & 97.51 & 99.94 \\
\hline $\mathrm{Si}$ & 11.940 & 10.669 & 11.790 & 11.386 & 11.403 & 10.107 & 11.424 & 11.964 & 11.993 & 12.029 & 11.893 \\
\hline $\mathrm{Ti}$ & 0.000 & 0.002 & 0.004 & 0.000 & 0.001 & 0.009 & 0.001 & 0.004 & 0.000 & 0.000 & 0.001 \\
\hline $\mathrm{Al}$ & 3.893 & 4.845 & 4.010 & 3.681 & 3.851 & 5.305 & 3.895 & 3.879 & 3.860 & 3.947 & 3.893 \\
\hline $\mathrm{Cr}$ & 0.007 & 0.006 & 0.000 & 0.001 & 0.004 & 0.000 & 0.000 & 0.000 & 0.000 & 0.000 & 0.000 \\
\hline $\mathrm{Fe}^{2+}$ & 0.002 & 0.008 & 0.018 & 0.020 & 0.010 & 0.081 & 0.008 & 0.008 & 0.000 & 0.008 & 0.014 \\
\hline $\mathrm{Mn}$ & 0.001 & 0.000 & 0.004 & 0.002 & 0.000 & 0.000 & 0.004 & 0.007 & 0.000 & 0.000 & 0.001 \\
\hline $\mathrm{Mg}$ & 0.010 & 0.003 & 0.005 & 0.004 & 0.001 & 0.026 & 0.000 & 0.006 & 0.001 & 0.006 & 0.005 \\
\hline $\mathrm{Ca}$ & 0.002 & 0.894 & 0.002 & 0.118 & 0.077 & 1.638 & 0.035 & 0.000 & 0.000 & 0.002 & 0.005 \\
\hline $\mathrm{Na}$ & 0.195 & 4.895 & 0.587 & 7.089 & 6.146 & 3.978 & 6.508 & 0.196 & 0.281 & 0.248 & 0.672 \\
\hline $\mathrm{K}$ & 4.315 & 0.064 & 4.148 & 0.036 & 0.495 & 0.151 & 0.012 & 4.257 & 4.161 & 3.762 & 4.022 \\
\hline Total & 20.365 & 21.384 & 20.569 & 22.336 & 21.988 & 21.295 & 21.888 & 20.319 & 20.297 & 20.003 & 20.506 \\
\hline An $(\%)$ & 0.049 & 15.269 & 0.047 & 1.628 & 1.140 & 28.405 & 0.541 & 0.000 & 0.009 & 0.046 & 0.098 \\
\hline $\mathrm{Ab}(\%)$ & 4.318 & 83.637 & 12.399 & 97.879 & 91.493 & 68.979 & 99.278 & 4.391 & 6.327 & 6.187 & 14.293 \\
\hline Or $(\%)$ & 95.632 & 1.093 & 87.553 & 0.493 & 7.367 & 2.616 & 0.181 & 95.609 & 93.664 & 93.767 & 85.608 \\
\hline
\end{tabular}

Franzinelli and Potter (1983) studied 95 sand samples from the Amazon River system in Brazil, Peru, Ecuador, and Colombia. This river system, with great contrasts in climate and rock types, reveals that sands derived from the Andes are lithic arenites, whereas sands derived from Precambrian shields are much richer in quartz, as are sands in rivers flowing from Tertiary molasse (Figs. 3, 11). River sands of Precambrian watersheds are coarser than those derived either directly from the Andes or from Tertiary molasse, for two probable reasons: (1) Precambrian granites have coarser quartz than the reworked quartz of a major geosyncline and (2) tropical weathering eliminates quartz-feldspathic rock fragments much more rapidly than quartz. Sand becomes more mature downstream along the main stem of the Amazon-Solimoes-Maranon so that a sample analyzed at the mouth does not accurately reflect headwater sand composition. Dilution by quartz-rich tributaries and quartz-rich Tertiary outcrops, possible differential elimination of rock fragments, and even possible weathering on the modern flood plain of the Amazon contributes to enhanced maturity downstream. Ladin et al. (1978) studied heavy minerals of the Amazon River sands and found most to contain idiomorphic, unstable heavy minerals such as hypersthene, augite, and amphibole, which diminish in abundance downstream as zircon and tourmaline become more abundant. 
Table 3 (continued).

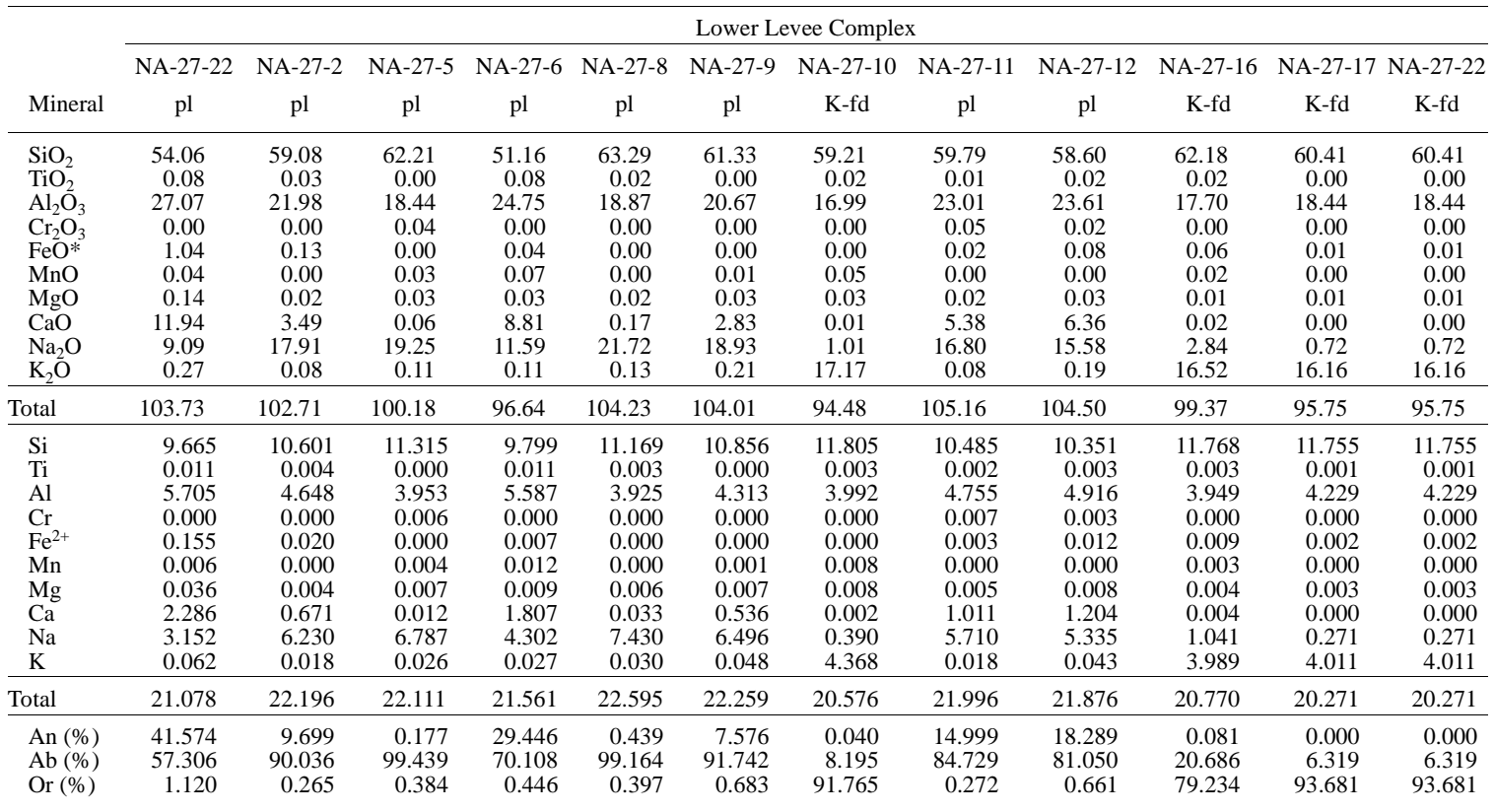

Table 3 (continued).

\begin{tabular}{|c|c|c|c|c|c|c|c|c|c|c|c|c|c|}
\hline \multirow[b]{3}{*}{ Mineral } & \multicolumn{13}{|c|}{ Deep Levee Complex } \\
\hline & NA-34-1 & NA-34-2 & NA-34-3 & NA-34-4 & NA-34-10 & NA-34-15 & NA-34-18 & NA-34-19 & NA-34-20 & NA-34-16 & NA-34-15 & NA-34-18 & 3 NA-34-19 \\
\hline & K-fd & $\mathrm{K}-\mathrm{fd}$ & $\mathrm{pl}$ & $\mathrm{K}-\mathrm{fd}$ & $\mathrm{K}-\mathrm{fd}$ & $\mathrm{pl}$ & $\mathrm{pl}$ & K-fd & $\mathrm{pl}$ & K-fd & K-fd & $\mathrm{pl}$ & K-fd \\
\hline $\mathrm{SiO}_{2}$ & 59.67 & 59.06 & 51.76 & 57.33 & 60.71 & 53.22 & 45.60 & 56.19 & 56.69 & 59.28 & 59.56 & 46.37 & 59.67 \\
\hline $\mathrm{TiO}_{2}$ & 0.03 & 0.00 & 0.01 & 0.01 & 0.00 & 0.00 & 0.02 & 0.02 & 0.00 & 0.04 & 0.00 & 0.08 & 0.00 \\
\hline $\mathrm{Al}_{2} \mathrm{O}_{3}$ & 19.52 & 19.69 & 23.63 & 18.38 & 21.35 & 25.00 & 29.00 & 19.57 & 22.13 & 20.40 & 20.92 & 28.57 & 21.19 \\
\hline $\mathrm{Cr}_{2} \mathrm{O}_{3}$ & 0.00 & 0.01 & 0.00 & 0.00 & 0.01 & 0.02 & 0.00 & 0.05 & 0.07 & 0.01 & 0.00 & 0.00 & 0.00 \\
\hline $\mathrm{FeO}^{*}$ & 0.04 & 0.08 & 0.20 & 0.00 & 0.11 & 0.19 & 0.03 & 0.11 & 0.02 & 0.04 & 0.05 & 0.45 & 0.04 \\
\hline $\mathrm{MnO}$ & 0.01 & 0.00 & 0.00 & 0.04 & 0.00 & 0.00 & 0.01 & 0.00 & 0.03 & 0.02 & 0.04 & 0.05 & 0.04 \\
\hline $\mathrm{MgO}$ & 0.03 & 0.03 & 0.04 & 0.03 & 0.04 & 0.05 & 0.02 & 0.01 & 0.05 & 0.02 & 0.03 & 0.07 & 0.04 \\
\hline $\mathrm{CaO}$ & 0.00 & 0.02 & 5.33 & 0.01 & 0.00 & 5.95 & 11.57 & 0.17 & 0.08 & 0.15 & 0.00 & 10.73 & 0.02 \\
\hline $\mathrm{Na}_{2} \mathrm{O}$ & 1.58 & 1.65 & 15.18 & 0.94 & 0.81 & 15.64 & 9.93 & 4.09 & 22.34 & 1.24 & 0.93 & 10.76 & 3.06 \\
\hline $\mathrm{K}_{2} \mathrm{O}$ & 17.51 & 17.14 & 0.84 & 18.14 & 17.14 & 0.80 & 0.01 & 15.02 & 0.05 & 19.69 & 19.05 & 0.63 & 14.92 \\
\hline Total & 98.39 & 97.68 & 96.99 & 94.87 & 100.17 & 100.85 & 96.20 & 95.22 & 101.46 & 100.88 & 100.58 & 97.69 & 98.98 \\
\hline $\mathrm{Si}$ & 11.455 & 11.412 & 9.948 & 11.485 & 11.357 & 9.848 & 8.865 & 11.176 & 10.397 & 11.246 & 11.259 & 8.928 & 11.269 \\
\hline $\mathrm{Ti}$ & 0.004 & 0.000 & 0.002 & 0.002 & 0.000 & 0.000 & 0.003 & 0.003 & 0.000 & 0.006 & 0.000 & 0.011 & 0.000 \\
\hline $\mathrm{Al}$ & 4.418 & 4.484 & 5.352 & 4.340 & 4.708 & 5.452 & 6.646 & 4.588 & 4.784 & 4.560 & 4.661 & 6.483 & 4.717 \\
\hline $\mathrm{Cr}$ & 0.000 & 0.002 & 0.000 & 0.000 & 0.002 & 0.003 & 0.000 & 0.007 & 0.010 & 0.001 & 0.000 & 0.000 & 0.000 \\
\hline $\mathrm{Fe}^{2+}$ & 0.006 & 0.012 & 0.033 & 0.000 & 0.017 & 0.029 & 0.004 & 0.018 & 0.003 & 0.006 & 0.008 & 0.072 & 0.007 \\
\hline $\mathrm{Mn}$ & 0.002 & 0.000 & 0.000 & 0.006 & 0.001 & 0.000 & 0.002 & 0.000 & 0.004 & 0.003 & 0.006 & 0.007 & 0.006 \\
\hline $\mathrm{Mg}$ & 0.008 & 0.010 & 0.011 & 0.008 & 0.010 & 0.013 & 0.005 & 0.003 & 0.014 & 0.004 & 0.008 & 0.020 & 0.011 \\
\hline $\mathrm{Ca}$ & 0.000 & 0.004 & 1.097 & 0.003 & 0.000 & 1.180 & 2.410 & 0.036 & 0.016 & 0.031 & 0.001 & 2.213 & 0.003 \\
\hline $\mathrm{Na}$ & 0.590 & 0.618 & 5.655 & 0.364 & 0.295 & 5.610 & 3.744 & 1.575 & 7.945 & 0.456 & 0.342 & 4.015 & 1.121 \\
\hline $\mathrm{K}$ & 4.288 & 4.225 & 0.206 & 4.635 & 4.090 & 0.188 & 0.002 & 3.811 & 0.012 & 4.766 & 4.594 & 0.155 & 3.594 \\
\hline Total & 20.771 & 20.767 & 22.304 & 20.842 & 20.481 & 22.323 & 21.682 & 21.217 & 23.184 & 21.079 & 20.879 & 21.905 & 20.730 \\
\hline An $(\%)$ & 0.000 & 0.090 & 15.770 & 0.052 & 0.000 & 16.909 & 39.144 & 0.664 & 0.197 & 0.592 & 0.012 & 34.671 & 0.069 \\
\hline $\mathrm{Ab}(\%)$ & 12.087 & 12.752 & 81.270 & 7.270 & 6.733 & 80.401 & 60.816 & 29.052 & 99.647 & 8.689 & 6.927 & 62.897 & 23.756 \\
\hline Or $(\%)$ & 87.913 & 87.158 & 2.960 & 92.679 & 93.267 & 2.690 & 0.040 & 70.284 & 0.156 & 90.719 & 93.061 & 2.432 & 76.175 \\
\hline
\end{tabular}

Potter $(1984,1986)$ studied the petrography and provenance of modern South American beach sands and divided them into five major associations. The Brazilian association, which extends for over $7000 \mathrm{~km}$ from the Rio de la Plata to Trinidad, is the most mature with a Q:F:R ratio of 91:4:5. Petrographic types of beach sands are quartz arenites and subarkoses or arkoses, and the Qm/Q ratio of 0.953 is the highest of all the South American beaches. Also, the K-fd/Fd ratio of 0.709 is also the highest, reflecting the input of both granites and gneisses of the Brazilian and Guiana Shields and the greater stability of potash feldspar over plagioclase in weathering, especially the tropical weathering that prevails over much of the continent bordered by this association. Furthermore, volcanic rock fragments are virtually absent except for a very few derived from the Cretaceous basalts of southwestern Brazil. Modal compositions of Amazon Fan sands are plotted on a ternary diagram and compared with those of Amazon River sediments (Franzinelli and Potter, 1983; Fig. 3). This figure reasonably indicates that the composition of the Amazon Fan sands is an average of those of the Precambrian and Paleozoic terrains and Andean terrain.

In order to aid provenance studies, heavy minerals are usually grouped into genetic suites, including reworked sedimentary, lowand high-grade metamorphic, sialic and mafic igneous, pegmatic, and authigenic suites (Hubert, 1971). Following Hubert's concept, I propose a five-fold subdivision of mineral assemblages in the Amazon 
Table 4. EMPA analyses of detrital amphiboles from the Amazon Fan.

\begin{tabular}{|c|c|c|c|c|c|c|c|c|c|c|c|c|c|c|c|c|}
\hline & & & & & & & & \multicolumn{9}{|c|}{ Middle Levee Complex } \\
\hline & \multicolumn{7}{|c|}{ Upper Levee Complex } & \multicolumn{3}{|c|}{ Unit $\mathrm{R}$} & \multicolumn{6}{|c|}{ Red } \\
\hline & NA-1-2 & NA-1-10 & NA-8-4 & NA-10-4 & NA-10-9 & NA-10-13 & NA-10-11 & NA-14-1 & NA-14-5 & NA-14-9 & NA-25-2 & NA-25-3 & NA-25-4 & NA-25-11 & NA-25-12 & NA-25-14 \\
\hline $\mathrm{SiO}_{2}$ & 44.05 & 44.54 & 43.53 & 43.03 & 44.89 & 43.42 & 47.02 & 50.15 & 45.87 & 46.71 & 42.40 & 43.62 & 40.34 & 49.37 & 41.13 & 46.13 \\
\hline $\begin{array}{l}\mathrm{SiO}_{2} \\
\mathrm{TiO}_{2}\end{array}$ & 2.64 & 0.76 & 1.40 & 2.01 & 1.30 & 1.44 & 1.97 & 1.45 & 1.18 & 0.95 & 2.57 & 0.50 & 2.98 & 0.26 & 3.63 & 1.11 \\
\hline $\mathrm{Al}_{2} \mathrm{O}_{3}$ & 10.41 & 12.25 & 8.88 & 9.29 & 9.52 & 7.95 & 7.27 & 5.75 & 9.77 & 6.49 & 12.35 & 13.80 & 13.00 & 2.70 & 10.52 & 5.46 \\
\hline $\mathrm{Cr}_{2} \mathrm{O}_{3}$ & 0.14 & 0.00 & 0.01 & 0.02 & 0.00 & 0.04 & 0.15 & 0.01 & 0.06 & 0.07 & 0.00 & 0.00 & 0.01 & 0.01 & 0.00 & 0.00 \\
\hline $\mathrm{FeO} *$ & 9.94 & 14.89 & 16.85 & 16.69 & 15.77 & 17.38 & 13.64 & 13.27 & 17.37 & 12.50 & 12.74 & 16.43 & 10.94 & 18.44 & 12.03 & 16.77 \\
\hline $\mathrm{MnO}$ & 0.13 & 0.44 & 0.48 & 0.27 & 0.45 & 0.45 & 0.32 & 0.55 & 0.40 & 0.48 & 0.09 & 0.34 & 0.09 & 0.64 & 0.20 & 0.36 \\
\hline $\mathrm{MgO}$ & 15.14 & 10.70 & 9.99 & 10.29 & 11.53 & 11.05 & 12.95 & 14.60 & 10.57 & 14.02 & 14.09 & 9.45 & 14.56 & 12.03 & 14.33 & 12.35 \\
\hline $\mathrm{CaO}$ & 11.42 & 11.77 & 11.53 & 11.33 & 12.25 & 12.18 & 11.25 & 10.91 & 10.95 & 11.03 & 11.72 & 9.98 & 11.94 & 12.07 & 11.53 & 12.20 \\
\hline $\mathrm{Na}_{2} \mathrm{O}$ & 5.56 & 3.02 & 2.17 & 3.22 & 2.62 & 2.33 & 1.83 & 2.82 & 2.25 & 2.66 & 4.65 & 4.13 & 4.86 & 0.79 & 4.96 & 1.66 \\
\hline $\mathrm{K}_{2} \mathrm{O}$ & 0.71 & 0.78 & 1.17 & 2.00 & 1.16 & 1.10 & 0.20 & 0.58 & 0.45 & 0.50 & 0.79 & 0.50 & 0.86 & 0.29 & 0.72 & 0.62 \\
\hline Total & 100.12 & 99.14 & 96.00 & 98.14 & 99.48 & 97.33 & 96.60 & 100.09 & 98.86 & 95.40 & 101.38 & 98.75 & 99.58 & 96.61 & 99.04 & 96.66 \\
\hline $\mathrm{Si}$ & 6.346 & 6.540 & 6.700 & 6.531 & 6.632 & 6.620 & 6.935 & 7.138 & 6.706 & 6.990 & 6.084 & 6.418 & 5.904 & 7.407 & 6.084 & 6.964 \\
\hline $\mathrm{Al}$ (IV) & $\begin{array}{l}0.654 \\
\end{array}$ & $\begin{array}{l}1.460 \\
\end{array}$ & 1.300 & $\begin{array}{l}1.469 \\
\end{array}$ & $\begin{array}{l}1.368 \\
1.36\end{array}$ & $\begin{array}{l}.0020 \\
1.380\end{array}$ & $\begin{array}{l}1.065 \\
\text { lo }\end{array}$ & 0.862 & 1.294 & $\begin{array}{l}1.010 \\
\text { lo }\end{array}$ & $\begin{array}{l}1.016 \\
1.916\end{array}$ & $\begin{array}{l}1.582 \\
1.58\end{array}$ & 2.096 & 0.593 & 1.916 & 1.036 \\
\hline $\mathrm{Al}(\mathrm{VI})$ & 0.114 & 0.660 & 0.310 & 0.191 & 0.289 & 0.047 & 0.198 & 0.103 & 0.389 & 0.135 & 0.173 & 0.811 & 0.146 & -0.115 & -0.083 & -0.065 \\
\hline $\mathrm{Ti}$ & 0.285 & 0.084 & 0.161 & 0.229 & 0.144 & 0.165 & 0.219 & 0.155 & 0.130 & 0.107 & 0.277 & 0.056 & 0.328 & 0.030 & 0.403 & 0.126 \\
\hline $\mathrm{Cr}$ & 0.015 & 0.000 & 0.001 & 0.003 & 0.000 & 0.005 & 0.017 & 0.001 & 0.006 & 0.008 & 0.000 & 0.000 & 0.001 & 0.001 & 0.000 & 0.000 \\
\hline $\mathrm{Fe}^{+3}$ & 0.000 & 0.000 & 0.000 & 0.000 & 0.000 & 0.119 & 0.300 & 0.241 & 0.490 & 0.249 & 0.152 & 0.245 & 0.010 & 0.485 & 0.000 & 0.298 \\
\hline $\mathrm{Fe}^{+2}$ & 1.197 & 1.827 & 2.168 & 2.117 & 1.948 & 2.096 & 1.382 & 1.339 & 1.634 & 1.316 & 1.376 & 1.776 & 1.328 & 1.828 & 1.487 & 1.818 \\
\hline $\mathrm{Mn}$ & 0.016 & 0.055 & 0.062 & 0.035 & 0.056 & 0.058 & 0.040 & 0.067 & 0.049 & 0.060 & 0.010 & 0.042 & 0.011 & 0.082 & 0.025 & $\begin{array}{l}1.040 \\
0.046\end{array}$ \\
\hline $\mathrm{Mg}$ & 3.248 & 2.339 & 2.290 & 2.327 & 2.537 & 2.509 & 2.844 & 3.095 & 2.302 & 3.126 & 3.011 & 2.071 & 3.175 & 2.689 & 3.158 & 2.778 \\
\hline $\mathrm{Ca}$ & $\begin{array}{l}1.762 \\
1.762\end{array}$ & 1.850 & 1.901 & 1.841 & 1.939 & 1.989 & $\begin{array}{l}1.0477 \\
1.777\end{array}$ & 1.663 & 1.714 & 1.768 & 1.801 & 1.572 & 1.872 & $\begin{array}{l}.0 .039 \\
1.939\end{array}$ & $\begin{array}{l}1.1027 \\
1.827\end{array}$ & 1.973 \\
\hline $\mathrm{Na}$ & $\begin{array}{l}1.102 \\
1.551\end{array}$ & $\begin{array}{l}1.800 \\
0.858\end{array}$ & 0.647 & $\begin{array}{l}1.841 \\
0.945\end{array}$ & 0.749 & 0.687 & 0.522 & $\begin{array}{l}.003 \\
0.777\end{array}$ & 0.637 & $\begin{array}{l}1.108 \\
0.771\end{array}$ & $\begin{array}{l}1.801 \\
1.292\end{array}$ & 1.178 & $\begin{array}{l}1.872 \\
1.378\end{array}$ & $\begin{array}{l}1.939 \\
0.229\end{array}$ & 1.421 & 0.486 \\
\hline $\mathrm{K}$ & 0.130 & 0.145 & 0.230 & 0.386 & 0.218 & 0.214 & 0.037 & 0.106 & 0.083 & 0.096 & 0.144 & 0.093 & 0.160 & 0.055 & 0.136 & 0.119 \\
\hline Total & 16.318 & 15.818 & 15.772 & 16.074 & 15.880 & 15.890 & 15.337 & 15.546 & 15.435 & 15.636 & 16.236 & 15.843 & 16.410 & 15.223 & 16.375 & 15.578 \\
\hline
\end{tabular}

Note: $\mathrm{FeO}^{*}=$ total $\mathrm{Fe}$ as $\mathrm{FeO}$.

Table 4 (continued).

Lower Levee Complex

Green

Deep Levee Complex

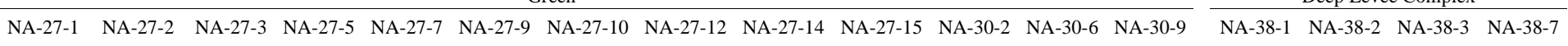

\begin{tabular}{|c|c|c|c|c|c|c|c|c|c|c|c|c|c|c|c|c|c|}
\hline $\mathrm{SiO}_{2}$ & 50.74 & 39.96 & 51.63 & 40.19 & 42.80 & 51.06 & 47.56 & 44.04 & 47.19 & 52.77 & 42.52 & 42.04 & 49.18 & 43.78 & 51.37 & 46.03 & 46.71 \\
\hline $\mathrm{TiO}_{2}^{2}$ & 0.56 & 2.45 & 0.23 & 3.26 & 2.59 & 0.08 & 1.12 & 1.22 & 0.74 & 0.11 & 2.27 & 2.64 & 1.30 & 0.33 & 1.10 & 0.43 & 0.67 \\
\hline $\mathrm{Al}_{2} \mathrm{O}_{3}$ & 4.43 & 12.84 & 6.11 & 9.57 & 11.56 & 7.56 & 6.90 & 10.75 & 7.14 & 2.99 & 9.90 & 11.19 & 7.40 & 14.18 & 5.56 & 12.75 & 8.74 \\
\hline $\mathrm{Cr}_{2} \mathrm{O}_{3}$ & 0.00 & 0.00 & 0.00 & 0.03 & 0.00 & 0.03 & 0.00 & 0.01 & 0.07 & 0.04 & 0.03 & 0.01 & 0.05 & 0.00 & 0.02 & 0.06 & 0.00 \\
\hline $\mathrm{FeO}^{3}$ & 17.36 & 10.26 & 13.01 & 25.39 & 12.22 & 6.31 & 15.17 & 14.84 & 16.39 & 11.98 & 12.64 & 10.33 & 18.39 & 12.84 & 12.27 & 16.62 & 16.84 \\
\hline $\mathrm{MnO}$ & 0.44 & 0.15 & 0.22 & 0.86 & 0.21 & 0.13 & 0.27 & 0.36 & 0.45 & 0.46 & 0.23 & 0.13 & 0.48 & 0.38 & 0.50 & 0.27 & 0.42 \\
\hline $\mathrm{MgO}$ & 11.34 & 13.83 & 14.06 & 3.84 & 13.44 & 17.21 & 12.05 & 11.05 & 11.37 & 15.16 & 13.51 & 14.69 & 11.84 & 12.18 & 15.98 & 10.00 & 11.07 \\
\hline $\mathrm{CaO}$ & 11.82 & 11.97 & 11.97 & 10.21 & 11.07 & 11.24 & 11.10 & 11.34 & 10.69 & 12.22 & 11.32 & 11.54 & 11.68 & 12.14 & 12.46 & 12.15 & 11.94 \\
\hline $\mathrm{Na}_{2} \mathrm{O}$ & 1.18 & 4.80 & 1.19 & 5.87 & 4.73 & 2.79 & 2.09 & 3.01 & 2.25 & 0.86 & 4.63 & 4.98 & 1.45 & 3.54 & 2.40 & 2.04 & 1.63 \\
\hline $\mathrm{K}_{2} \mathrm{O}$ & 0.34 & 1.06 & 0.45 & 1.77 & 0.76 & 0.11 & 0.49 & 0.77 & 0.42 & 0.17 & 0.45 & 0.76 & 0.54 & 0.37 & 0.58 & 0.60 & 0.52 \\
\hline Total & 98.22 & 97.32 & 98.86 & 100.98 & 99.37 & 96.52 & 96.74 & 97.37 & 96.71 & 96.75 & 97.50 & 98.30 & 102.31 & 99.74 & 102.23 & 100.95 & 98.55 \\
\hline $\mathrm{Si}$ & 7.481 & 5.978 & 7.375 & 6.261 & 6.260 & 7.273 & 7.076 & 6.593 & 7.032 & 7.674 & 6.359 & 6.194 & 6.924 & 6.328 & 7.162 & 6.617 & 6.867 \\
\hline $\mathrm{Al}$ (IV) & 0.519 & 2.022 & 0.625 & 1.739 & 1.740 & 0.727 & 0.924 & 1.407 & 0.968 & 0.326 & 1.641 & 1.806 & 1.076 & 1.672 & 0.838 & 1.383 & 1.133 \\
\hline $\mathrm{Al}(\mathrm{VI})$ & 0.251 & 0.242 & 0.403 & 0.017 & 0.251 & 0.542 & 0.286 & 0.489 & 0.286 & 0.187 & 0.105 & 0.136 & 0.152 & 0.743 & 0.076 & 0.776 & 0.381 \\
\hline $\mathrm{Ti}$ & 0.062 & 0.275 & 0.024 & 0.382 & 0.285 & 0.009 & 0.125 & 0.138 & 0.083 & 0.012 & 0.255 & 0.292 & 0.137 & 0.035 & 0.115 & 0.046 & 0.074 \\
\hline $\mathrm{Cr}$ & 0.000 & 0.000 & 0.000 & 0.003 & 0.000 & 0.003 & 0.000 & 0.001 & 0.009 & 0.004 & 0.003 & 0.001 & 0.006 & 0.000 & 0.003 & 0.007 & 0.000 \\
\hline $\mathrm{Fe}^{+3}$ & 0.008 & 0.000 & 0.100 & 0.000 & 0.000 & 0.000 & 0.157 & 0.000 & 0.369 & 0.034 & 0.000 & 0.000 & 0.632 & 0.042 & 0.058 & 0.089 & 0.280 \\
\hline $\mathrm{Fe}^{+2}$ & 2.132 & 1.283 & 1.454 & 3.306 & 1.495 & 0.752 & 1.730 & 1.857 & 1.674 & 1.423 & 1.581 & 1.272 & 1.532 & 1.510 & 1.371 & 1.908 & 1.789 \\
\hline Mn & 0.055 & 0.019 & 0.027 & 0.113 & 0.026 & 0.016 & 0.034 & 0.045 & 0.057 & 0.056 & 0.030 & 0.016 & 0.057 & 0.047 & 0.058 & 0.033 & 0.052 \\
\hline $\mathrm{Mg}$ & 2.491 & 3.082 & 2.992 & 0.890 & 2.928 & 3.651 & 2.670 & 2.464 & 2.524 & 3.284 & 3.011 & 3.223 & 2.483 & 2.623 & 3.318 & 2.141 & 2.424 \\
\hline $\mathrm{Ca}$ & 1.867 & 1.918 & 1.831 & $\begin{array}{l}1.704 \\
\text { S }\end{array}$ & 1.734 & 1.714 & 1.769 & 1.818 & 1.706 & 1.903 & 1.814 & 1.821 & 1.761 & 1.879 & 1.860 & 1.870 & 1.880 \\
\hline $\mathrm{Na}$ & 0.337 & 1.391 & $\begin{array}{l}.0 .328 \\
0.328\end{array}$ & 1.773 & $\begin{array}{l}1.339 \\
\end{array}$ & 0.771 & 0.601 & 0.874 & 0.649 & 0.241 & 1.341 & 1.423 & 0.395 & 0.990 & 0.648 & 0.569 & 0.465 \\
\hline $\mathrm{K}$ & 0.065 & 0.202 & 0.082 & 0.352 & 0.142 & 0.020 & 0.093 & 0.146 & 0.079 & 0.031 & 0.085 & 0.142 & 0.096 & 0.069 & 0.102 & 0.111 & 0.098 \\
\hline Total & 15.269 & 16.411 & 15.242 & 16.540 & 16.200 & 15.478 & 15.463 & 15.831 & 15.434 & 15.174 & 16.225 & 16.325 & 15.252 & 15.938 & 15.610 & 15.550 & 15.444 \\
\hline
\end{tabular}



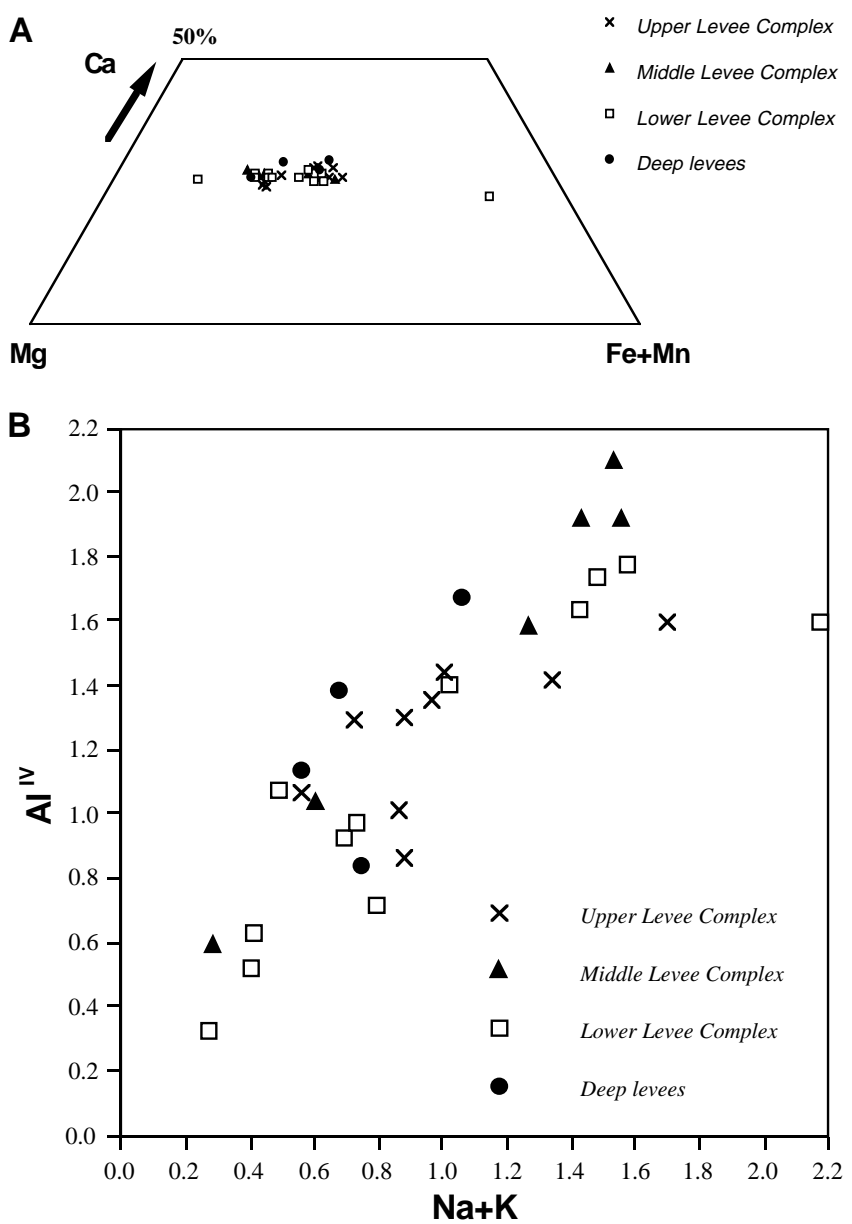

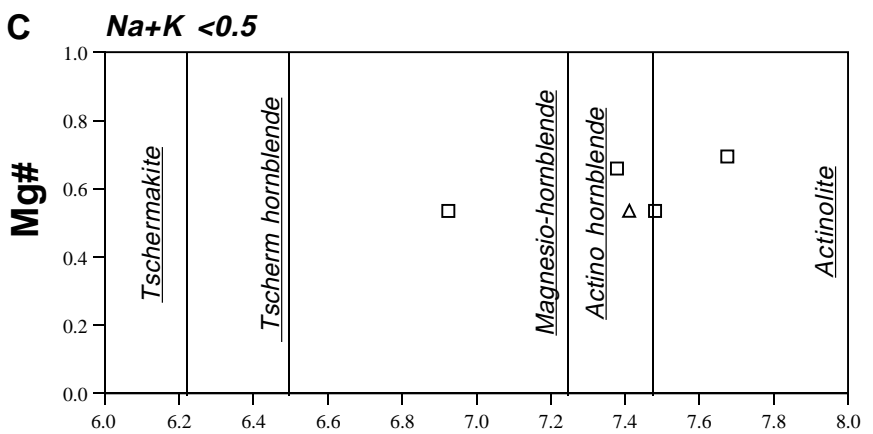

Si

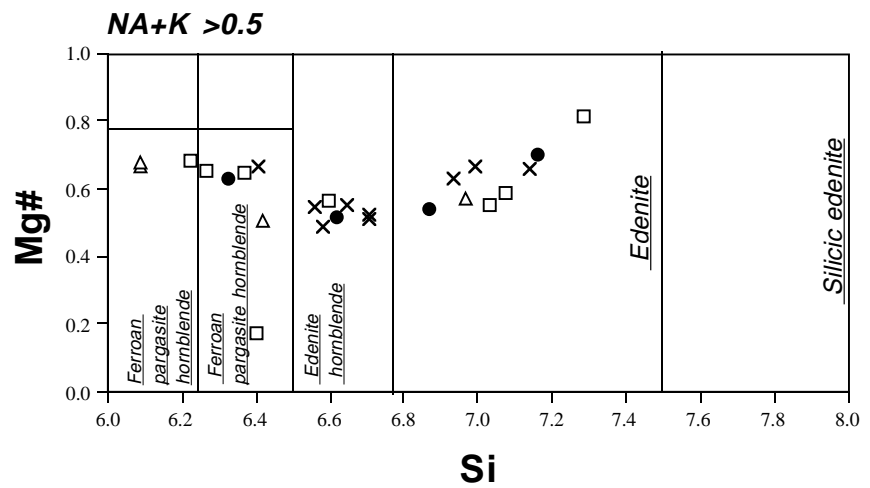

$\times \quad$ Upper Levee Complex $\quad \square \quad$ Lower Levee Complex

$\Delta \quad$ Middle Levee Complex $\quad \bullet \quad$ Deep levees

Figure 5. A. Amphibole compositions of Amazon Fan sediments plotted on a Ca-Mg-Fe $+\mathrm{Mn}$ diagram. B. $\mathrm{Na}+\mathrm{K}$ vs. $\mathrm{Al}^{\mathrm{IV}}$ diagram of detrital amphiboles in Amazon Fan sediments. C. Si vs. $\mathrm{Mg} \#\left(=\mathrm{mg}\left[\mathrm{Mg}+\mathrm{Fe}^{2+}\right]\right)$ diagrams of detrital amphibole grains in Amazon Fan sediments. The nomenclature of amphiboles is based on Leake (1978).

Fan sands (Table 12). The M-group mineral assemblage contains staurolite, kyanite, sillimanite, chloritoid, garnet (almandine to pyrope), and mica schist fragments, and it is characteristic of mediumpressure type metamorphic rocks at moderate (epidote-amphibolite to amphibolite facies) to high grades (granulite facies). The $\mathbf{M}^{*}$ group mineral assemblage contains high-grossular garnet and is characteristic of high-grade metamorphic rocks (high-pressure type; eclogite facies?). The $\mathrm{V}$-group mineral assemblage contains augite, hypersthene, hornblende, chromian spinel (high-Ti type), and volcanic rock fragments (volcanic glass, dacite, and basalt to andesite). The S-group mineral assemblage contains quartzite, iron-stained quartz (round type), zircon (round type), rutile (round type), and tourmaline (round type). The P-group mineral assemblage contains euhedral zircon and tourmaline, hornblende, $\mathrm{K}$-feldspar, and plutonic rock fragments characteristic of granitoids.

The $\mathrm{M}$-group and $\mathrm{M}^{*}$-group mineral assemblages are interpreted to be derived from the Precambrian rocks of the Guiana and Brazilian Shields (Gibbs and Barron, 1983; Hasui and de Almeida, 1985; Teixeira et al., 1989), or the foreland region of Andes (Basu et al., 1990; Potter, 1994). The V-group mineral assemblage is interpreted to be directly derived from arc-volcanic rocks of the Andean Cordillera, and has been reworked with Tertiary and Quaternary deposits in the Amazon River. There are few feldspar grains from the Andes, because most were presumably altered to kaolinite by tropical weathering during transportation. Like the $\mathrm{M}$ - and $\mathrm{M}^{*}$-groups, the S-group mineral assemblage is sourced from either the Paleozoic to Tertiary sediments of the Amazon Basin or is directly derived from the Precambrian shields, as are the P-group minerals, which could derive from the Andean Cordillera or from the Precambrian shields.

\section{CONCLUSIONS}

1. I identified 38 species of detrital grains ( 34 minerals and four rock fragments) by optical microscope analysis. The fine sand to silt grains consist of quartz (70\% to $80 \%$ ), feldspar (8\% to $15 \%)$, and mica $(\sim 1 \%)$. Accessory heavy minerals (5\% to $7 \%$ ) include zircon, tourmaline, hornblende, clinopyroxene, orthopyroxene, staurolite, kyanite, sillimanite, chloritoid, and garnet. Opaque oxide minerals constitute $2 \%$ to $5 \%$. Wellrounded quartz grains have iron-rich surface coatings. In terms of petrographic types, the Amazon Fan sands are quartz arenite to subarkose.

2. The modal and chemical compositions of the Amazon Fan sands show no temporal variations throughout the sections and stratigraphic horizons.

3. I propose five categories of mineral assemblages in the Amazon Fan sand following the scheme of Hubert (1971). These include: $\mathrm{M}$-group = medium-pressure type metamorphic rocks; $\mathrm{M}^{*}$-group = high-pressure type metamorphic rocks; $\mathrm{P}$ group $=$ granitic rocks; $\mathrm{S}$-group $=$ recycled sediments; and $\mathrm{V}$ group $=$ arc-volcanic rocks 

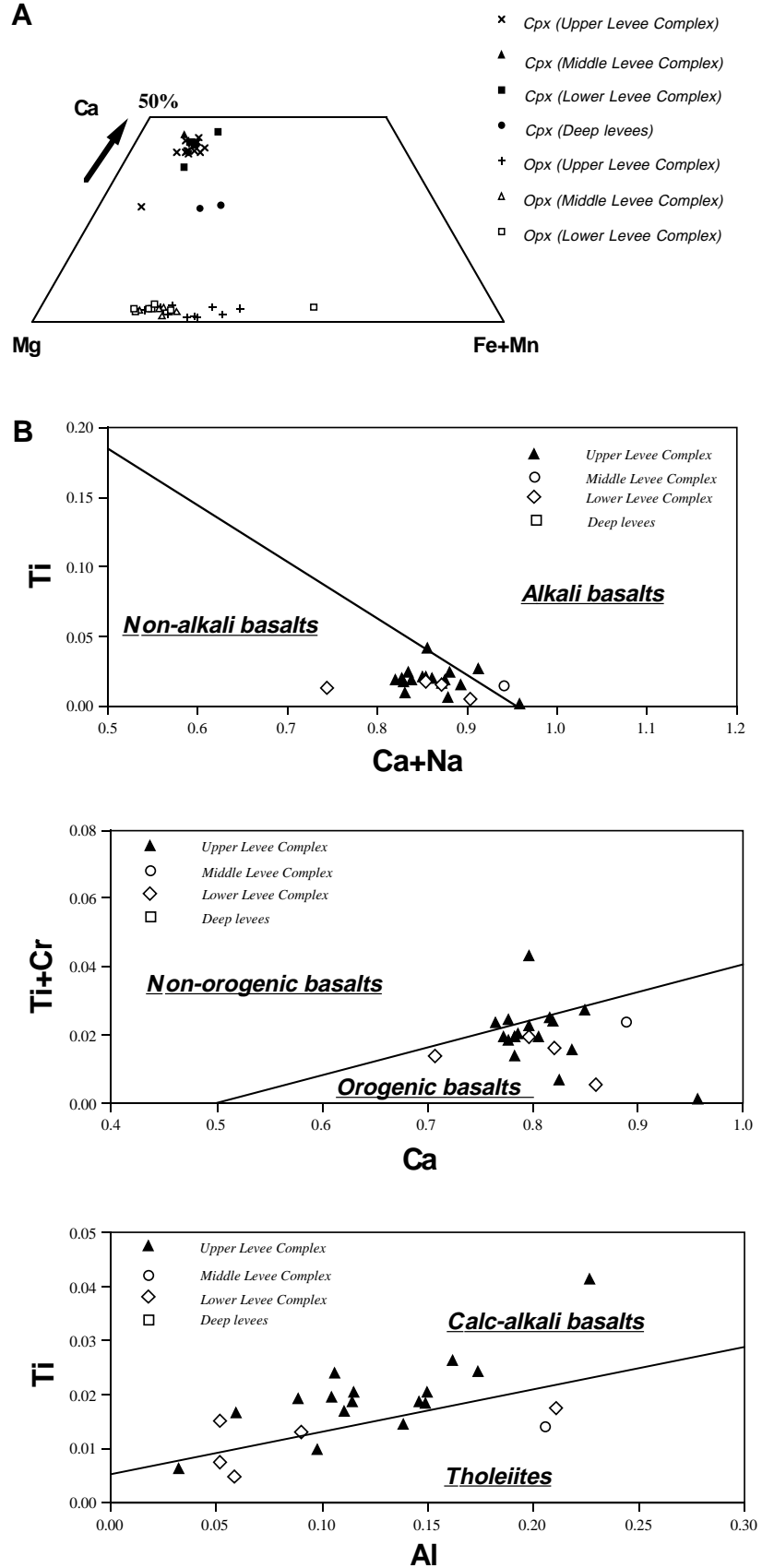

Figure 6. A. Chemical composition of pyroxene grains from Amazon Fan sediments, plotted on a Ca-Mg-Fe $+\mathrm{Mn}$ diagram. B. Discrimination diagrams of detrital clinopyroxene from Amazon Fan sediments. Fields from Leterrier et al. (1982).

4. The $\mathrm{M}$ - and $\mathbf{M}^{*}$-group mineral assemblages are interpreted to be supplied by the Precambrian rocks of the Guiana and Brazilian Shields or the foreland region of the Andes. The Vgroup mineral assemblage is derived from arc-volcanic rocks of the Andean Cordillera and reworked along with Tertiary and Quaternary deposits in the Amazon River. The S-group mineral assemblage derives from the Amazon Basin (Paleozoic to Tertiary) or directly derived from the Precambrian shields. The P-group mineral assemblage is derived from granitoids of the Andean Cordillera or from the Precambrian shields.

\section{ACKNOWLEDGMENTS}

I am very grateful to Dr. T. Nakajima for discussions and suggestions on the rock-forming mineralogy, as well as a critical reading of this manuscript, and Prof. H. Okada, Drs. S. Tokuhashi, S. Miyazaki, S. Togashi, M. Nakagawa, and E. Ohta for help in modal and chemical analyses and heavy mineral separations throughout this study. I also thank Mr. T. Sato for preparation of thin sections and polished sections for EMPA. I wish to thank the co-chief scientists of Leg 155, Drs. R.D. Flood, D.J.W. Piper, and Drs. A. Klaus, S. McLennan, and P.E. Potter for their helpful suggestions.

\section{REFERENCES}

Arai, S., 1990. What kind of magmas could be equilibrated with ophiolitic peridotites? In Malpas, J. (Ed.), Ophiolites, Oceanic Crustal Analogues. Proc. Symp. “TROODOS 1987”: Nicosia (Geol. Surv., Minuets.), 557565.

1992. Chemistry of chromian spinel in volcanic rocks as a potential guide to magma chemistry. Mineral. Mag., 56:173-184.

Basu, A.R., Sharma, M., and DeCelles, P.G., 1990. Nd, Sr-isotopic provenance and trace element geochemistry of Amazonian foreland basin fluvial sands, Bolivia and Peru: implications for ensialic Andean Orogeny, Earth Planet. Sci. Lett., 100:1-17.

Bouma, A.H., 1962. Sedimentology of Some Flysch Deposits: A Graphic Approach to Facies Interpretation: Amsterdam (Elsevier).

Carneiro de Castro, J., Miura, K., and Estrela-Braga, J.A., 1978. Stratigraphic and structural framework of the Foz do Amazonas Basin. Proc. Annu. Offshore Techno. Conf., 3:1843-1848.

Chopin, C., and Monie, P., 1984. A unique magnesiochloritoid-bearing, highpressure assemblage from the Monte Rosa, Western Alps: petrologic and ${ }^{40} \mathrm{Ar}-{ }^{39} \mathrm{Ar}$ radiometric study. Contrib. Mineral. Petrol., 87:388-398.

Coleman, R.G., Lee, D.E., Beatty, L.B., and Brannock, W.W., 1965. Eclogites and eclogites: their differences and similarities. Geol. Soc. Amer. Bull., 76:483-508.

Damuth, J.E., and Fairbridge, R.W., 1970. Equatorial Atlantic deep-sea arkosic sands and ice-age aridity in tropical South America. Geol. Soc. Am. Bull., 81:189-206.

Damuth, J.E., Flood, R.D., Kowsmann, R.O., Belderson, R.H., and Gorini, M.A., 1988. Anatomy and growth pattern of Amazon deep-sea fan as revealed by long-range side-scan sonar (GLORIA) and high-resolution seismic studies. AAPG Bull., 72:885-911.

Damuth, J.E., and Kumar, N., 1975. Amazon Cone: Morphology, sediments, age, and growth pattern. Geol. Soc. Am. Bull., 86:863-878.

Deer, W.A., Howie, R.A., and Zussman, J., 1982. Rock-Forming Minerals (2nd ed.): London (Longman).

Dickinson, W.R., 1982. Compositions of sandstones in circum-Pacific subduction complexes and fore-arc basins. AAPG Bull., 66:121-137.

Dickinson, W.R., Beard, L.S., Brackenbridge, G.R., Erjavec, J.L., Ferguson, R.C., Inman, K.F., Knepp, R.A., Lindberg, F.A., and Ryberg, P.T., 1983. Provenance of North American Phanerozoic sandstones in relation to tectonic setting. Geol. Soc. Am. Bull., 94:222-235.

Dickinson, W.R., and Suczek, C.A., 1979. Plate tectonics and sandstone composition. AAPG Bull., 63:2164-2182.

Dollase, W.A., 1971. Refinement of the crystal structures of epidote, allanite and hancockite. Am. Mineral., 56:447-464.

Enami, M., and Banno, S., 1980. Zoisite-clinozoisite relations in low- to medium-grade high-pressure metamorphic rocks and their implications. Mineral. Mag., 43:1005-1013.

Flood, R.D., Manley, P.L., Kowsmann, R.O., Appi, C.J., and Pirmez, C., 1991. Seismic facies and late Quaternary growth of Amazon submarine fan. In Weimer, P., and Link, M.H. (Eds.), Seismic Facies and Sedimentary Processes of Modern and Ancient Submarine Fans: New York (Springer-Verlag), 415-433.

Flood, R.D., Piper, D.J.W., Klaus, A., et al., 1995. Proc. ODP, Init. Repts., 155: College Station TX (Ocean Drilling Program).

Franzinelli, E., and Potter, P.E., 1983. Petrology, chemistry and texture of modern river sands, Amazon River system. J. Geol., 91:23-39.

Fuhrman, M.L., and Lindsley, D.H., 1988. Ternary-feldspar modeling and thermometry. Am. Mineral., 73:201-215.

Gentry, A.H., and Lopez-Parodi, J., 1980. Deforestation and increased flooding of the Upper Amazon. Science, 210:1354-1354. 


\section{F. NANAYAMA}

Gibbs, A.K., and Barron, C.N., 1983. The Guiana Shield reviewed. Episodes, $2: 7-14$.

Gibbs, R.J., 1967. The geochemistry of the Amazon River system. Part I.The factors that control the salinity and the composition and concentration of the suspended solids. Geol. Soc. Am. Bull., 78:1203-1232.

Hasui, Y., and de Almeida, F.F.M., 1985. The Central Brazil Shield reviewed, Episodes, 8:29-37.

Hubert, J.F., 1971. Analysis of Heavy-mineral Assemblages. In Carver, R.E., (Ed.), Procedures in Sedimentary Petrology: New York (John Wiley), 453-478.

Kronberg, B.I., Nesbitt, H.W., and Lam, W.W., 1986. Upper Pleistocene Amazon deep-sea fan muds reflect intense chemical weathering of their mountainous source lands. Chem. Geol., 54:283-294.

Kuehl, S.A., Nittrouer, C.A., and DeMaster, D.J., 1982. Modern sediment accumulation and strata formation on the Amazon continental shelf. Mar. Geol., 49:279-200.

Ladin, P.M.B., Bosio, N.J., Wu, F.T., Meyer, A.E., Jr., and Castro, P.R.M., 1978. Heavy minerals from the Amazon bed. Eos, 59:277.

Leake, B.E., 1978. Nomenclature of amphiboles. Mineral. Mag., 42:533563.

Leterrier, J., Maury, R.C., Thonon, P., Girard, D., and Marchal, M., 1982. Clinopyroxene composition as a method of identification of the magmatic affinities of paleo-volcanic series. Earth Planet. Sci. Lett., 59:139154.

Liou, J.G., 1973. Synthesis and stability relations of epidote, $\mathrm{Ca}_{2} \mathrm{Al}_{2} \mathrm{FeSiO}_{12}(\mathrm{OH})$. J. Petrol., 14:381-413.

Manley, P.L., and Flood, R.D., 1988. Cyclic sediment deposition within Amazon deep-sea fan. AAPG Bull., 72:912-925.

Miyashiro, A., 1953. Calcium-poor garnet in relation to metamorphism. Geochim. Cosmochim. Acta, 4:179-208.

Miyashiro, A., and Seki, Y., 1958. Enlargement of the composition field of epidote and piemontite with rising temperature. Am. J. Sci., 256:423430.

Nakajima, T., Banno, S., and Suzuki, T., 1977. Reactions leading to the disappearance of pumpellyite in low-grade metamorphic rocks of the san- bagawa metamorphic belt in central Shikoku, Japan. J. Petrol., 18:263284.

Nesbitt, H.W., MacRae, N.D., and Kronberg, B.I., 1990. Amazon deep-sea fan muds: light REE enriched products of extreme chemical weathering. Earth Planet. Sci. Lett., 100:118-123.

Nittrouer, C.A., Kuehl, S.A., DeMaster, D.J., and Kowsmann, R.O., 1986. The deltaic nature of Amazon Shelf sedimentation. Geol. Soc. Am. Bull., 97:444-458.

Nittrouer, C.A., DeMaster, D.J., Figueiredo, A.G., and Rine, J.M., 1991. AmasSeds: an interdisciplinary investigation of a complex coastal environment. Oceanography, 4:3-7.

Pettijohn, F.J., Potter, P.E., and Siever, R., 1987. Sand and Sandstone (2nd ed.): New York (Springer-Verlag).

Potter, P.E., 1984. South American modern beach sand and plate tectonics. Nature, 311:645-648.

Potter, P.E., 1986. South America and a few grains of Sand, Part I.-Beach Sands. J. Geol., 94:301-319.

Potter, P.E., 1994. Modern sands of South America: composition, provenance and global significance. Geol. Rundsch., 83:212-232.

Stow, D.A.V., Howell, D.G., and Nelson, C.H., 1985. Sedimentary, tectonic, and sea-level controls. In Bouma, A.H., Normark, W.R., and Barnes, N.E. (Eds.), Submarine Fans and Related Turbidite Systems: New York (Springer-Verlag): 15-22.

Teixeira, W., Tassinari, C.C.G., Cordani, U.G., and Kawashita, K., 1989. A Review of the Geochronology of the Amazonian Craton: tectonic implications. Precambrian Res., 30:213-227.

Trevena, A.S., and Nash, W.P., 1981. An electron microprobe study of detrital feldspar. J. Sediment. Petrol., 51:137-150.

Date of initial receipt: 4 December 1995

Date of acceptance: 29 July1996

Ms 155SR-204 
Table 5. EMPA analyses of detrital pyroxenes from the Amazon Fan.

\begin{tabular}{|c|c|c|c|c|c|c|c|c|c|c|c|c|c|c|c|}
\hline \multirow[b]{2}{*}{ Mineral } & \multicolumn{15}{|c|}{ Upper Levee Complex } \\
\hline & $\begin{array}{l}\text { NA-1-1 } \\
\text { cpx }\end{array}$ & $\begin{array}{l}\text { NA-1-3 } \\
\text { cpx }\end{array}$ & $\begin{array}{l}\text { NA-1-4 } \\
\text { cpx }\end{array}$ & $\begin{array}{l}\text { NA-1-5 } \\
\text { сpx }\end{array}$ & $\begin{array}{l}\text { NA-1-11 } \\
\text { opx }\end{array}$ & $\begin{array}{l}\text { NA-8-1 } \\
\text { opx }\end{array}$ & $\begin{array}{l}\text { NA-8-2 } \\
\text { cpx }\end{array}$ & $\begin{array}{l}\text { NA-8-3 } \\
\text { cpx }\end{array}$ & $\begin{array}{l}\text { NA-8-5 } \\
\text { cpx }\end{array}$ & $\begin{array}{l}\text { NA-8-6 } \\
\text { opx }\end{array}$ & $\begin{array}{c}\text { NA-8-7 } \\
\text { opx }\end{array}$ & $\begin{array}{l}\text { NA-8-8 } \\
\text { срх }\end{array}$ & $\begin{array}{c}\text { NA-8-10 } \\
\text { cpx }\end{array}$ & $\begin{array}{c}\text { NA-8-11 } \\
\text { opx }\end{array}$ & $\begin{array}{c}\text { NA-8-12 } \\
\text { cpx }\end{array}$ \\
\hline $\mathrm{SiO}_{2}$ & 52.81 & 52.06 & 51.68 & 50.93 & 55.90 & 53.93 & 52.02 & 49.70 & 51.87 & 52.76 & 52.86 & 49.88 & 51.58 & 53.76 & 37.73 \\
\hline $\mathrm{TiO}_{2}^{2}$ & 0.75 & 0.61 & 0.87 & 0.74 & 0.05 & 0.12 & 0.68 & 0.87 & 0.35 & 0.16 & 0.19 & 0.94 & 0.53 & 0.37 & 0.04 \\
\hline $\mathrm{Al}_{2} \mathrm{O}_{3}$ & 2.73 & 2.58 & 2.46 & 4.43 & 0.73 & 0.55 & 2.68 & 3.99 & 2.26 & 1.39 & 2.86 & 3.73 & 3.24 & 1.33 & 22.52 \\
\hline $\mathrm{Cr}_{2} \mathrm{O}_{3}$ & 0.00 & 0.19 & 0.04 & 0.14 & 0.03 & 0.00 & 0.03 & 0.05 & 0.28 & 0.03 & 0.29 & 0.06 & 0.08 & 0.03 & 0.00 \\
\hline $\mathrm{FeO} *$ & 9.12 & 6.93 & 8.77 & 7.06 & 23.10 & 19.86 & 8.07 & 7.57 & $\begin{array}{l}5.20 \\
5.99\end{array}$ & 19.47 & 13.99 & 7.53 & $\begin{array}{l}6.30 \\
6.32\end{array}$ & 15.95 & 12.38 \\
\hline $\mathrm{MnO}$ & 0.26 & 0.31 & 0.38 & 0.18 & 0.66 & 0.96 & $\begin{array}{l}0.01 \\
0.23\end{array}$ & 0.17 & 0.13 & 0.76 & 0.25 & 0.24 & 0.12 & 0.37 & 0.15 \\
\hline $\mathrm{MgO}$ & 14.68 & 15.84 & 15.15 & 14.95 & 17.04 & 22.62 & 15.39 & 14.71 & 16.73 & 23.46 & 26.51 & 14.51 & 15.79 & 25.39 & 0.05 \\
\hline $\mathrm{CaO}$ & 20.56 & 20.03 & 19.98 & 20.47 & 1.49 & 0.74 & 20.15 & 20.62 & 19.87 & 0.61 & 1.38 & 21.57 & 21.52 & 1.81 & 23.23 \\
\hline $\mathrm{Na}_{2} \mathrm{O}$ & 0.95 & 0.67 & 0.81 & 0.81 & 0.13 & 0.02 & 0.79 & 0.90 & 0.69 & 0.00 & 0.05 & 0.89 & 0.79 & 0.08 & 0.03 \\
\hline $\mathrm{K}_{2} \mathrm{O}$ & 0.00 & 0.00 & 0.01 & 0.01 & 0.01 & 0.00 & 0.00 & 0.00 & 0.00 & 0.00 & 0.00 & 0.00 & 0.01 & 0.01 & 0.00 \\
\hline Total & 101.86 & 99.21 & 100.14 & 99.72 & 99.14 & 98.80 & 100.03 & 98.57 & 98.17 & 98.64 & 98.38 & 99.35 & 99.98 & 99.09 & 96.12 \\
\hline $\mathrm{Si}$ & 1.917 & 1.927 & 1.906 & 1.875 & 2.094 & 2.011 & 1.914 & 1.853 & 1.927 & 1.969 & 1.930 & 1.848 & 1.887 & 1.967 & 1.501 \\
\hline $\mathrm{Al}$ (IV) & & & & & & & & 7 & & 0.0 & & $\begin{array}{l}1.040 \\
0.152\end{array}$ & $\begin{array}{l}1.001 \\
0.113\end{array}$ & & 0.499 \\
\hline $\mathrm{Al}(\mathrm{VI})$ & 0.034 & 0.039 & 0.013 & 0.067 & 0.032 & 0.024 & 0.031 & 0.028 & .026 & 0.030 & 3 & 0.011 & 0.026 & 0.025 & 0.558 \\
\hline $\mathrm{Ti}$ & 0.021 & 0.017 & 0.024 & 0.021 & 0.001 & 0.003 & 0.019 & 0.024 & 0.010 & 0.004 & 0.005 & 0.026 & 0.015 & 0.010 & 0.001 \\
\hline $\mathrm{Cr}$ & 0.000 & 0.005 & 0.001 & 0.004 & 0.001 & 0.000 & 0.001 & 0.001 & 0.008 & 0.001 & 0.008 & 0.002 & 0.002 & 0.001 & 0.000 \\
\hline $\mathrm{Fe}^{+2}$ & 0.074 & 0.043 & 0.090 & 0.071 & 0.000 & 0.000 & 0.073 & 0.135 & 0.070 & 0.000 & 0.002 & 0.151 & 0.112 & 0.000 & 0.000 \\
\hline $\mathrm{Fe}^{+3}$ & 0.203 & 0.171 & 0.180 & 0.147 & 0.723 & 0.619 & 0.176 & 0.101 & 0.116 & 0.608 & 0.425 & 0.083 & 0.081 & 0.488 & 0.412 \\
\hline $\mathrm{Mn}$ & 0.008 & 0.010 & 0.01 & 0.006 & 0.021 & 0.030 & 0.007 & 0.005 & 0.004 & 0.024 & 0.008 & 0.008 & 0.004 & 0.011 & 0.005 \\
\hline $\mathrm{Mg}$ & 0.794 & 0.873 & & 0.820 & 0.951 & 1.2 & 0.8 & 0.817 & 0.9 & 1.3 & 1. & 0.801 & 0.860 & & 0.003 \\
\hline $\mathrm{Ca}$ & 0.800 & 0.794 & & 0.807 & 0.060 & 0.029 & 0.7 & 0.823 & 0.790 & 0.024 & 0.054 & 0.856 & 0.843 & 0.071 & 0.990 \\
\hline $\mathrm{Na}$ & 0.067 & 0.048 & 0.058 & 0.058 & 0.009 & 0.002 & 0.056 & 0.065 & 0.050 & 0.000 & 0.003 & 0.064 & 0.056 & 0.006 & 0.002 \\
\hline & 0.000 & 0.000 & 0.000 & 0.001 & 0.001 & 0.000 & 0.000 & 0.000 & 0.000 & 0.000 & 0.000 & 0.000 & 0.001 & 0.000 & 0.000 \\
\hline $\mathrm{Fe}+\mathrm{Mn}$ & 0.082 & 0.053 & 0.102 & 0.076 & 0.021 & 0.030 & 0.080 & 0.140 & 0.074 & 0.024 & 0.010 & 0.158 & 0.116 & 0.011 & 0.005 \\
\hline Total & 4.000 & 4.000 & 4.000 & 4.000 & 3.893 & 3.975 & 4.000 & 4.000 & 4.000 & 3.996 & 4.000 & 4.000 & 4.000 & 3.996 & 3.971 \\
\hline CaTs (\%) & 8.254 & 7.348 & 9.40 & 12.488 & 0.00 & 0.000 & 8.5 & 14.7 & 7.3 & 3.0 & 7.027 & 15.216 & 11.348 & 3.254 & 49.862 \\
\hline & 61.8 & 61 & & & & & & & & & -0 . & & & 1.9 & 59.084 \\
\hline En + & 24.12 & 27.483 & 26.8 & 24.294 & 95.894 & 98.341 & 26.393 & 21.019 & 27.551 & 97.245 & 93.612 & 16.088 & 18.842 & 94.475 & -9.233 \\
\hline Jd-Acm (\%) & 5.743 & 4.058 & 4.918 & 4.932 & 0.548 & 0.089 & 4.796 & 5.649 & 4.241 & 0.000 & 0.172 & 5.707 & 4.983 & 0.303 & 0.287 \\
\hline
\end{tabular}

Notes: $\mathrm{cpx}=$ clinopyroxene; opx = orthopyroxene; $\mathrm{CaTs}=\mathrm{Ca}$-tschermakite; $\mathrm{Di}=$ diopsite $\mathrm{Hd}=$ hedenbergite $; \mathrm{En}=$ enstatite; Fs = forsterite; $\mathrm{Jd}=\mathrm{jadeite} ; \mathrm{Acm}=\mathrm{acmite} ; \mathrm{FeO} *$ = total Fe as $\mathrm{FeO}$. 
Table 5 (continued).

Upper Levee Complex

Unit R

NA-8-13 NA-8-14 NA-8-15 NA-10-1 NA-10-3 NA-10-5 NA-10-6 NA-10-10 NA-10-11 NA-10-13 NA-14-1 NA-14-3 NA-14-6 NA-14-7 NA-14-8

\begin{tabular}{|c|c|c|c|c|c|c|c|c|c|c|c|c|c|c|c|}
\hline Mineral & opx & opx & opx & opx & $\operatorname{cpx}$ & $\operatorname{cpx}$ & cpx & cpx & cpx & cpx & opx & $\operatorname{cpx}$ & $\operatorname{cpx}$ & cpx & opx \\
\hline $\mathrm{SiO}_{2}$ & 52.21 & 51.77 & 52.59 & 53.80 & 50.08 & 52.65 & 51.81 & 53.08 & 50.95 & 57.84 & 53.66 & 50.39 & 53.67 & 52.38 & 52.80 \\
\hline $\mathrm{TiO}_{2}$ & 0.23 & 0.13 & 0.11 & 0.39 & 1.52 & 0.72 & 0.69 & 0.71 & 0.50 & 0.02 & 0.18 & 0.65 & 0.22 & 0.59 & 0.28 \\
\hline $\mathrm{Al}_{2} \mathrm{O}_{3}$ & 1.44 & 0.55 & 1.43 & 1.47 & 5.33 & 2.46 & 3.45 & 2.10 & 3.12 & 0.27 & 0.78 & 3.41 & 0.76 & 1.36 & 1.17 \\
\hline $\mathrm{Cr}_{2} \mathrm{O}_{3}$ & 0.00 & 0.04 & 0.01 & 0.18 & 0.13 & 0.00 & 0.37 & 0.00 & 0.76 & 0.01 & 0.03 & 0.34 & 0.03 & 0.12 & 0.04 \\
\hline $\mathrm{FeO}^{*}$ & 22.34 & 23.89 & 21.00 & 17.43 & 7.43 & 7.77 & 7.11 & 7.68 & 6.07 & 5.39 & 16.80 & 6.79 & 7.86 & 7.33 & 16.14 \\
\hline $\mathrm{MnO}$ & 0.72 & 0.49 & 0.71 & 0.45 & 0.12 & 0.18 & 0.16 & 0.30 & 0.11 & 0.12 & 0.63 & 0.22 & 0.33 & 0.13 & 0.40 \\
\hline $\mathrm{MgO}$ & 21.29 & 20.46 & 22.78 & 24.76 & 14.59 & 15.18 & 15.37 & 16.42 & 16.93 & 21.42 & 24.67 & 15.56 & 14.90 & 15.48 & 24.74 \\
\hline $\mathrm{CaO}$ & 1.76 & 0.94 & 0.47 & 1.96 & 20.58 & 20.85 & 21.26 & 20.17 & 21.12 & 13.37 & 0.91 & 19.23 & 21.17 & 19.69 & 1.43 \\
\hline $\mathrm{Na}_{2} \mathrm{O}$ & 0.09 & 0.05 & 0.05 & 0.07 & 0.86 & 0.82 & 0.82 & 0.79 & 0.78 & 0.17 & 0.11 & 0.77 & 0.78 & 1.34 & 0.10 \\
\hline $\mathrm{K}_{2} \mathrm{O}$ & 0.01 & 0.00 & 0.00 & 0.02 & 0.01 & 0.02 & 0.00 & 0.01 & 0.02 & 0.01 & 0.03 & 0.01 & 0.01 & 0.00 & 0.01 \\
\hline Total & 100.07 & 98.31 & 99.15 & 100.53 & 100.62 & 100.63 & 101.02 & 101.25 & 100.36 & 98.63 & 97.80 & 97.37 & 99.74 & 98.42 & 97.11 \\
\hline $\mathrm{Si}$ & 1.949 & 1.981 & 1.965 & 1.955 & 1.832 & 1.927 & 1.884 & 1.924 & 1.850 & 2.076 & 1.994 & 1.896 & 1.988 & 1.949 & 1.974 \\
\hline $\mathrm{Al}$ (IV) & 0.051 & 0.019 & 0.035 & 0.045 & 0.168 & 0.073 & 0.116 & 0.076 & 0.150 & 0.000 & 0.006 & 0.104 & 0.012 & 0.051 & 0.026 \\
\hline $\mathrm{Al}(\mathrm{VI})$ & 0.013 & 0.006 & 0.028 & 0.018 & 0.062 & 0.033 & 0.032 & 0.013 & -0.016 & 0.011 & 0.028 & 0.047 & 0.021 & 0.009 & 0.026 \\
\hline $\mathrm{Ti}$ & 0.006 & 0.004 & 0.003 & 0.011 & 0.042 & 0.020 & 0.019 & 0.019 & 0.014 & 0.001 & 0.005 & 0.018 & 0.006 & 0.017 & 0.008 \\
\hline $\mathrm{Cr}$ & 0.000 & 0.001 & 0.000 & 0.005 & 0.004 & 0.000 & 0.010 & 0.000 & 0.022 & 0.000 & 0.001 & 0.010 & 0.001 & 0.004 & 0.001 \\
\hline $\mathrm{Fe}^{+2}$ & 0.032 & 0.007 & 0.004 & 0.007 & 0.080 & 0.059 & 0.094 & 0.080 & 0.173 & 0.000 & 0.000 & 0.066 & 0.034 & 0.102 & 0.000 \\
\hline $\mathrm{Fe}^{+3}$ & 0.666 & 0.757 & 0.652 & 0.523 & 0.147 & 0.179 & 0.122 & 0.153 & 0.011 & 0.162 & 0.522 & 0.148 & 0.210 & 0.126 & 0.505 \\
\hline $\mathrm{Mn}$ & 0.023 & 0.016 & 0.022 & 0.014 & 0.004 & 0.005 & 0.005 & 0.009 & 0.003 & 0.004 & 0.020 & 0.007 & 0.010 & 0.004 & 0.013 \\
\hline $\mathrm{Mg}$ & $\begin{array}{l}1.184 \\
\end{array}$ & $\begin{array}{l}1.167 \\
1.06\end{array}$ & 1.268 & 1.340 & 0.795 & 0.828 & 0.832 & 0.886 & 0.916 & 1.145 & $\begin{array}{l}.020 \\
1.366\end{array}$ & 0.872 & 0.822 & 0.858 & $\begin{array}{l}.00 \\
1.378\end{array}$ \\
\hline $\mathrm{Ca}$ & $\begin{array}{l}1.104 \\
0.070\end{array}$ & 0.038 & 0.019 & 0.076 & 0.806 & 0.817 & 0.828 & 0.783 & 0.822 & 0.514 & 0.036 & 0.775 & 0.840 & $\begin{array}{l}0.785 \\
0.785\end{array}$ & 0.057 \\
\hline $\mathrm{Na}$ & 0.006 & 0.003 & 0.003 & 0.005 & 0.061 & 0.058 & 0.058 & 0.056 & 0.055 & 0.012 & 0.008 & 0.056 & 0.056 & 0.096 & 0.007 \\
\hline $\mathrm{K}$ & 0.000 & 0.000 & 0.000 & 0.001 & 0.000 & 0.001 & 0.000 & 0.000 & 0.001 & 0.001 & 0.0 & 0.000 & 0.000 & 0.000 & 0.000 \\
\hline $\mathrm{Fe}+\mathrm{Mn}$ & 0.055 & 0.023 & 0.027 & 0.021 & 0.084 & 0.064 & 0.099 & 0.089 & 0.176 & 0.004 & 0.020 & 0.073 & 0.044 & 0.107 & 0.013 \\
\hline Total & 4.000 & 4.000 & 4.000 & 4.000 & 4.000 & 4.000 & 4.000 & 4.000 & 4.000 & 3.924 & 3.988 & 4.000 & 4.000 & 4.000 & 3.995 \\
\hline CaTs & 5.052 & 1.860 & 3.488 & 4.484 & 16.794 & 7.279 & 11.604 & 7.627 & 14.979 & 0.000 & 0.565 & 10.403 & 1.216 & 5.118 & 2.570 \\
\hline $\mathrm{Di}+\mathrm{Hd}(\%)$ & 1.006 & 1.007 & -0.801 & $\begin{array}{l}1.602 \\
\end{array}$ & 52.953 & 64.861 & 62.168 & 59.636 & 58.141 & 38.968 & 1.610 & 55.862 & $\begin{array}{l}75.189 \\
\text {. }\end{array}$ & 64.458 & 1.626 \\
\hline$E n+1$ & 93.627 & 96.956 & 97.138 & 93.648 & 25.224 & 22.825 & 21.200 & 28.043 & 22.117 & 60.140 & 97.417 & 29.078 & 18.523 & 21.966 & 95.424 \\
\hline Jd-Acm (\%) & 0.315 & 0.178 & 0.174 & 0.266 & 5.029 & 5.035 & 5.027 & 4.694 & 4.763 & 0.891 & 0.408 & 4.658 & 5.072 & 8.458 & 0.381 \\
\hline
\end{tabular}


Table 5 (continued).

Middle Level Complex

Lower Levee Complex

NA-25-6 NA-25-11.5 NA-25-7 NA-25-9 NA-25-10 NA-25-13 NA-25-15 NA-27-4 NA-27-6 NA-27-8 NA-27-11 NA-27-13 NA-27-17 NA-27-18 NA-27-19 NA-27-20 NA-30-3 NA-30-7

\begin{tabular}{|c|c|c|c|c|c|c|c|c|c|c|c|c|c|c|c|c|c|c|}
\hline Mineral & opx & cpx & opx & opx & opx & opx & cpx & opx & $\mathrm{cpx}$ & $\mathrm{cpx}$ & opx & cpx & cpx & opx & opx & opx & cpx & opx \\
\hline $\mathrm{SiO}_{2}$ & 53.80 & 49.33 & 53.15 & 53.63 & 52.99 & 54.08 & 48.35 & 55.42 & 54.93 & 51.56 & 51.22 & 53.05 & 52.27 & 53.37 & 55.20 & 53.89 & 52.21 & 55.20 \\
\hline $\mathrm{TiO}_{2}^{2}$ & 0.31 & 0.72 & 0.36 & 0.28 & 0.35 & 0.03 & 0.51 & 0.37 & 0.28 & 0.65 & 0.16 & 0.17 & 0.48 & 0.36 & 0.26 & 0.33 & 0.54 & 0.25 \\
\hline $\mathrm{Al}_{2} \mathrm{O}_{3}$ & 0.94 & 2.55 & 1.57 & 1.12 & 1.65 & 0.32 & 4.73 & 1.70 & 1.27 & 4.99 & 2.15 & 1.36 & 2.95 & 2.38 & 0.97 & 1.84 & 1.19 & 0.70 \\
\hline $\mathrm{Cr}_{2} \mathrm{O}_{3}$ & 0.00 & 0.25 & 0.05 & 0.00 & 0.03 & 0.00 & 0.67 & 0.00 & 0.03 & 0.14 & 0.00 & 0.04 & 0.05 & 0.00 & 0.02 & 0.04 & 0.06 & 0.00 \\
\hline $\mathrm{FeO} *$ & 18.38 & 8.06 & 16.64 & 14.36 & 16.19 & 15.88 & 5.70 & 15.14 & 12.75 & 6.77 & 27.78 & 9.31 & 7.93 & 12.99 & 14.59 & 17.00 & 7.66 & 15.27 \\
\hline $\mathrm{MnO}$ & 0.76 & $\begin{array}{l}0.00 \\
0.24\end{array}$ & $\begin{array}{r}0.04 \\
0.34\end{array}$ & 0.50 & 0.39 & $\begin{array}{r}1.00 \\
0.32\end{array}$ & 0.13 & 0.48 & 0.40 & 0.16 & $\begin{array}{r}1.108 \\
1.48\end{array}$ & 0.51 & 0.19 & 0.35 & 0.43 & 0.46 & 0.19 & 0.44 \\
\hline $\mathrm{MgO}$ & $\begin{array}{r}24.90 \\
24.99\end{array}$ & $\begin{array}{r}0.24 \\
15.63\end{array}$ & 25.93 & 28.54 & $\begin{array}{r}0.53 \\
26.36\end{array}$ & $\begin{array}{r}0.32 \\
24.16\end{array}$ & $\begin{array}{r}0.15 \\
15.90\end{array}$ & $\begin{array}{l}0.40 \\
26.75\end{array}$ & 28.05 & $\begin{array}{r}.10 \\
14.95\end{array}$ & $\begin{array}{r}10.94 \\
10.94\end{array}$ & $\begin{array}{r}0.01 \\
12.71\end{array}$ & $\begin{array}{r}0.19 \\
16.85\end{array}$ & $\begin{array}{r}0.35 \\
27.74\end{array}$ & $\begin{array}{r}26.45 \\
26.97\end{array}$ & $\begin{array}{r}0.40 \\
24.40\end{array}$ & $\begin{array}{l}0.19 \\
15.14\end{array}$ & $\begin{array}{r}0.44 \\
26.48\end{array}$ \\
\hline $\mathrm{CaO}$ & 1.29 & 19.30 & 1.87 & 1.58 & 1.70 & 0.60 & 22.44 & 1.57 & 1.56 & 20.70 & 1.36 & 21.97 & $\begin{array}{l}18.25 \\
\text { S }\end{array}$ & 1.25 & 1.58 & 1.43 & 20.80 & 2.13 \\
\hline $\mathrm{Na}_{2} \mathrm{O}$ & 0.09 & 0.75 & 0.09 & 0.07 & 0.03 & 0.09 & 0.75 & 0.15 & 0.12 & 0.83 & 0.57 & 0.62 & 0.53 & 0.14 & 0.13 & 0.18 & 0.72 & 0.06 \\
\hline $\begin{array}{l}\mathrm{K}_{2} \mathrm{O} \\
\end{array}$ & 0.01 & 0.01 & 0.01 & 0.01 & 0.00 & 0.01 & 0.01 & 0.02 & $\begin{array}{l}0.12 \\
0.01\end{array}$ & $\begin{array}{l}0.03 \\
0.01\end{array}$ & 0.04 & $\begin{array}{l}0.02 \\
0.03 \\
\end{array}$ & $\begin{array}{l}0.03 \\
0.01\end{array}$ & $\begin{array}{l}0.14 \\
0.02 \\
\end{array}$ & $\begin{array}{l}0.13 \\
0.01\end{array}$ & $\begin{array}{l}0.10 \\
0.03\end{array}$ & 0.01 & $\begin{array}{l}0.00 \\
0.02 \\
\end{array}$ \\
\hline Total & 100.57 & 96.82 & 100.01 & 100.09 & 99.69 & 95.49 & 99.20 & 101.60 & 99.39 & 100.74 & 95.69 & 99.77 & 99.50 & 98.59 & 100.17 & 99.60 & 98.53 & 100.55 \\
\hline $\mathrm{Si}$ & 1.958 & 1.872 & 1.927 & 1.917 & 1.923 & 2.040 & 1.787 & 1.966 & 1.972 & 1.877 & 2.059 & 1.988 & 1.925 & 1.931 & 1.982 & 1.969 & 1.954 & 1.98 \\
\hline $\mathrm{Al}$ (IV) & 0.042 & 0.128 & 0.073 & 0.083 & 0.077 & 0.000 & 0.213 & 0.034 & 0.028 & 0.123 & -0.059 & 0.012 & 0.075 & 0.069 & 0.018 & 0.031 & 0.046 & 0.016 \\
\hline $\mathrm{Al}(\mathrm{VI})$ & -0.002 & -0.014 & -0.006 & -0.036 & -0.007 & 0.014 & -0.007 & 0.037 & 0.026 & 0.091 & 0.161 & 0.048 & 0.053 & 0.033 & 0.023 & 0.048 & 0.007 & 0.01 . \\
\hline $\mathrm{Ti}$ & $\begin{array}{r}-0.002 \\
0.009\end{array}$ & $\begin{array}{r}-0.0014 \\
0.020\end{array}$ & $\begin{array}{r}-0.000 \\
0.010\end{array}$ & $\begin{array}{r}-0.030 \\
0.008\end{array}$ & $\begin{array}{r}-0.0010 \\
0.010\end{array}$ & $\begin{array}{l}0.014 \\
0.001\end{array}$ & $\begin{array}{r}-0.001 \\
0.014\end{array}$ & 0.010 & $\begin{array}{l}0.020 \\
0.008\end{array}$ & $\begin{array}{l}0.091 \\
0.018\end{array}$ & $\begin{array}{l}0.101 \\
0.005\end{array}$ & $\begin{array}{l}.0 .048 \\
0.005\end{array}$ & $\begin{array}{l}.053 \\
0.013\end{array}$ & $\begin{array}{l}.033 \\
0.010\end{array}$ & $\begin{array}{l}.023 \\
0.007\end{array}$ & $\begin{array}{l}0.048 \\
0.009\end{array}$ & 0.015 & 0.007 \\
\hline $\mathrm{Cr}$ & 0.000 & 0.008 & 0.001 & $\begin{array}{l}0.000 \\
0.000\end{array}$ & 0.001 & 0.000 & 0.020 & 0.000 & 0.001 & 0.004 & 0.000 & 0.001 & 0.001 & 0.000 & 0.001 & 0.001 & 0.002 & 0.000 \\
\hline $\mathrm{Fe}^{+2}$ & 0.034 & $\begin{array}{l}0.000 \\
0.150\end{array}$ & 0.066 & $\begin{array}{l}0.000 \\
0.110\end{array}$ & $\begin{array}{l}0.001 \\
0.066\end{array}$ & 0.000 & $\begin{array}{l}0.020 \\
0.176\end{array}$ & 0.000 & $\begin{array}{l}0.001 \\
0.000\end{array}$ & 0.052 & 0.000 & 0.000 & 0.033 & 0.027 & 0.000 & 0.000 & 0.060 & 0.000 \\
\hline $\mathrm{Fe}^{+3}$ & 0.526 & 0.106 & 0.439 & 0.319 & 0.425 & 0.501 & 0.000 & 0.449 & 0.383 & 0.155 & 0.934 & 0.292 & 0.211 & 0.366 & 0.438 & 0.519 & 0.180 & 0.45 \\
\hline $\mathrm{Mn}$ & 0.023 & 0.008 & 0.010 & 0.015 & 0.012 & 0.010 & 0.004 & 0.014 & 0.012 & 0.005 & 0.050 & 0.016 & 0.006 & 0.011 & 0.013 & 0.014 & 0.006 & 0.013 \\
\hline $\mathrm{Mg}$ & 1.354 & 0.883 & 1.400 & 1.519 & 1.425 & 1.358 & 0.876 & 1.413 & 1.500 & 0.811 & 0.655 & 0.709 & 0.924 & 1.495 & 1.442 & 1.328 & 0.844 & 1.418 \\
\hline $\mathrm{Ca}$ & 0.050 & 0.784 & 0.072 & 0.060 & 0.066 & 0.024 & 0.888 & 0.060 & 0.060 & 0.807 & 0.058 & 0.882 & 0.720 & 0.048 & 0.061 & 0.056 & 0.834 & 0.08 \\
\hline $\mathrm{Na}$ & 0.006 & 0.055 & 0.007 & 0.005 & 0.002 & 0.007 & 0.054 & 0.010 & 0.008 & 0.058 & 0.045 & 0.045 & 0.038 & 0.010 & 0.009 & 0.013 & 0.052 & 0.00 \\
\hline $\mathrm{K}$ & 0.000 & 0.000 & 0.001 & 0.000 & 0.000 & 0.001 & 0.001 & 0.001 & 0.000 & 0.000 & 0.002 & 0.001 & 0.000 & 0.001 & 0.000 & 0.001 & 0.001 & 0.00 \\
\hline $\mathrm{Fe}+\mathrm{Mn}$ & 0.057 & 0.158 & 0.076 & 0.125 & 0.078 & 0.010 & 0.180 & 0.014 & 0.012 & 0.056 & 0.050 & 0.016 & 0.039 & 0.038 & 0.013 & 0.014 & 0.066 & 0.013 \\
\hline Total & 4.000 & 4.000 & 4.000 & 4.000 & 4.000 & 3.955 & 4.025 & 3.994 & 3.997 & 4.000 & 3.909 & 3.999 & 4.000 & 4.000 & 3.995 & 3.989 & 4.000 & 3.997 \\
\hline CaTs (\%) & 4.236 & 12.830 & 7.316 & 8.350 & 7.726 & 0.000 & 21.300 & 3.425 & 2.797 & 12.305 & -5.860 & 1.188 & 7.512 & 6.881 & 1.784 & 3.136 & 4.597 & 1.618 \\
\hline $\mathrm{Di}+\mathrm{Hd}(\%)$ & 0.406 & 54.7 & -0.0 & -1.145 & -0.554 & 1.2 & 57.1 & 1.313 & 1.652 & 58. & 7.583 & 82.191 & 50 & -1.0 & 2.237 & 1.270 & 69.831 & 3.442 \\
\hline $\mathrm{En}+\mathrm{Fs}(\%)$ & 95.051 & 27.803 & 92.388 & 92.558 & 92.723 & 98.340 & 16.958 & 94.730 & 95.140 & 24.102 & 95.384 & 12.388 & 38.686 & 93. & 95.516 & 94.916 & 20.943 & 94.72 . \\
\hline Jd-Acm (\%) & 0.308 & 4.610 & 0.332 & 0.238 & 0.105 & 0.365 & 4.566 & 0.532 & 0.411 & 5.009 & 2.893 & 4.233 & 2.987 & 0.475 & 0.463 & 0.678 & 4.629 & 0.21 \\
\hline
\end{tabular}



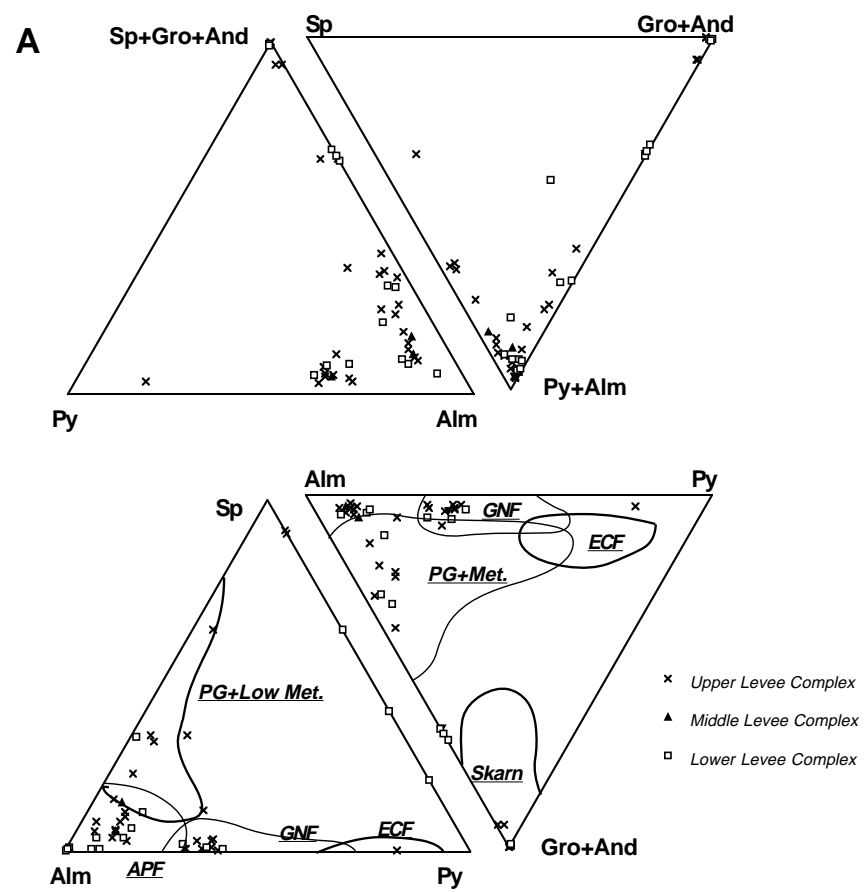

B

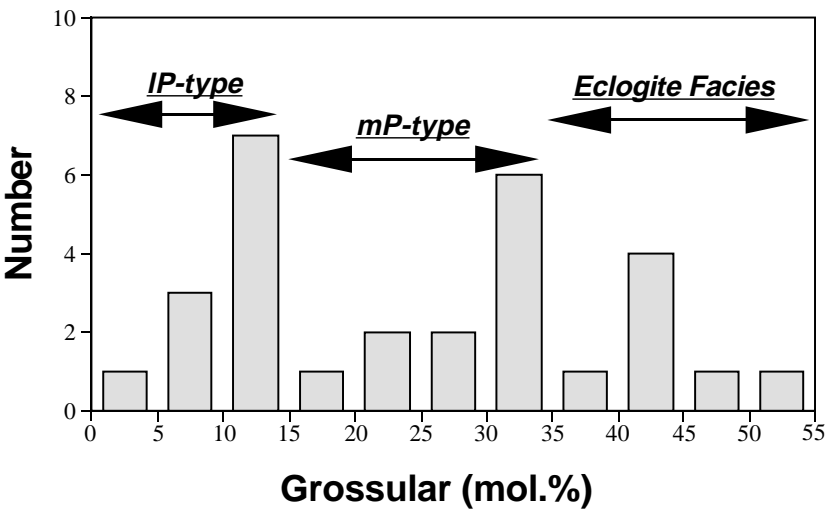

Figure 7. A. Chemical composition of garnet grains from Amazon Fan sediments, plotted on (Sp + Gro + And $)-\mathrm{Py}-\mathrm{Alm}, \mathrm{Sp}-(\mathrm{Gro}+\mathrm{And})-(\mathrm{Py}+\mathrm{Alm})$, Sp - Alm - Py, and Alm - Py - (Gro + And) diagrams. The four metamorphic fields encircled with solid lines are after Miyashiro (1953) and Deer et al. (1982). Sp = spessartine $; \mathrm{Gro}=$ grossular; $\mathrm{And}=$ andradite $\mathrm{Py}=$ pyrope $; \mathrm{Alm}=$ almandine $\mathrm{PG}=$ pegmatite $;$ Low met. = low metamorphic rock; $\mathrm{APF}=$ amphibolite facies; $\mathrm{ECF}=$ eclogite facies; Met. = metamorphic rock; GNF = granulite facies. B. Frequency distribution with respect to grossular content $(\mathrm{mol} \%)$ in detrital garnet from Amazon Fan sediments. IP-type = low pressure metamorphic rock series; $\mathrm{mP}=$ medium pressure metamorphic rock series.

Table 6. EMPA analyses of detrital garnets from the Amazon Fan.

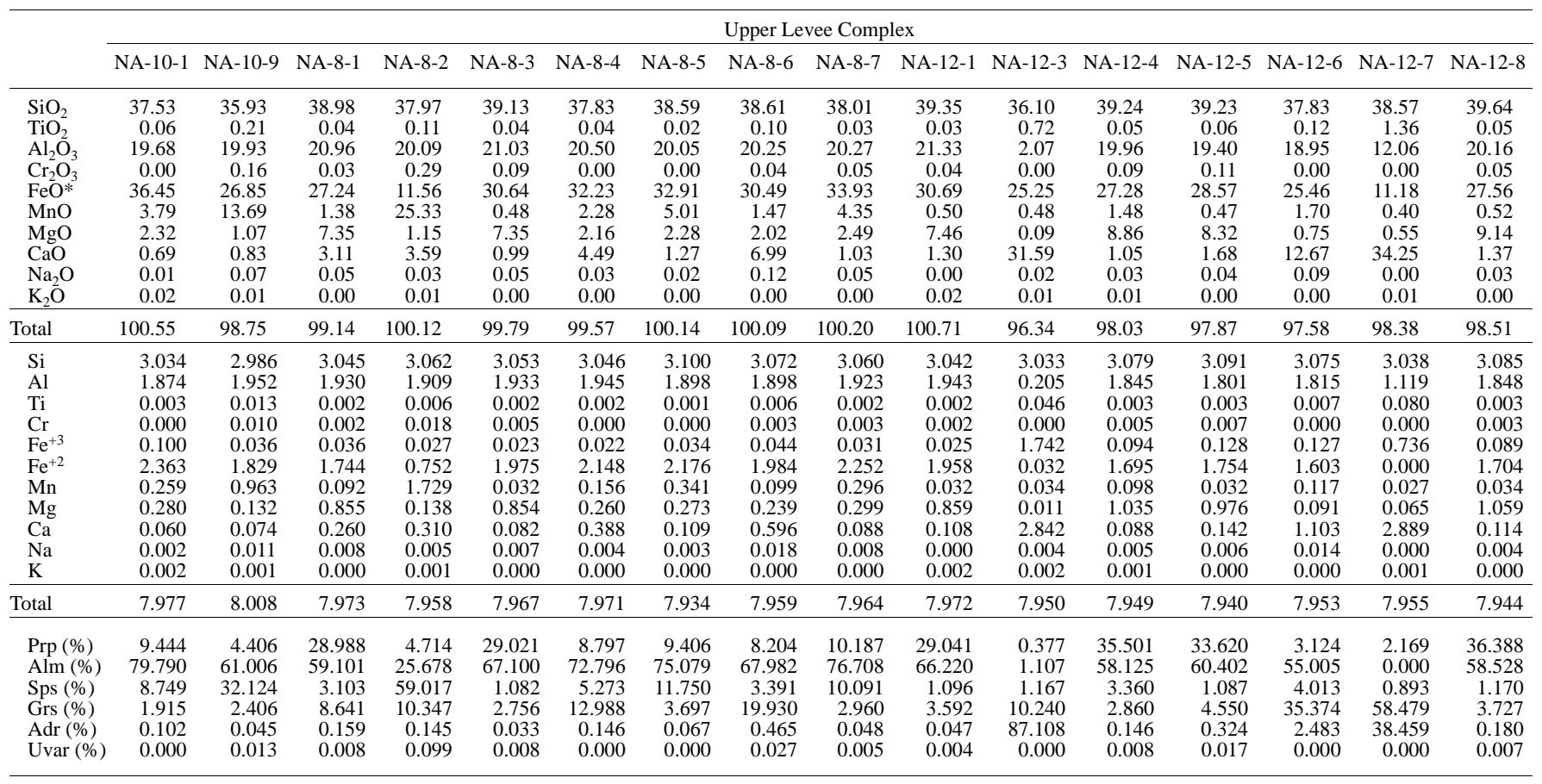

Notes: $\operatorname{Prp}=$ pyrope $;$ Alm = almandine $;$ Sps = spessartine $;$ Grs = grossular $;$ Adr = almandine; Uvar = uvarovite $; \mathrm{FeO} *=$ total Fe as FeO. 
Table 6 (continued).

\begin{tabular}{|c|c|c|c|c|c|c|c|c|c|c|c|c|c|c|c|}
\hline & \multicolumn{6}{|c|}{ Upper Levee Complex } & \multicolumn{4}{|c|}{ Unit R } & \multicolumn{3}{|c|}{ Middle Levee Complex } & \multicolumn{2}{|c|}{ Lower Levee Complex } \\
\hline & NA-12-1 & NA-12-4 & NA-12-5 & NA-12-6 & NA-12-7 & NA-12-8 & NA-14-4 & NA-14-2 & NA-14-3 & NA-14-1 & NA-25-1 & NA-25-2 & NA-25-01 & NA-25-02 & NA-27-1 \\
\hline $\mathrm{SiO}_{2}$ & 40.70 & 40.30 & 38.58 & 38.67 & 38.49 & 38.55 & 31.98 & 36.53 & 37.55 & 34.80 & 39.08 & 38.56 & 36.49 & 36.45 & 37.83 \\
\hline $\mathrm{TiO}_{2}$ & 0.03 & 0.04 & 0.05 & 0.16 & 0.03 & 0.00 & 0.04 & 0.14 & 0.05 & 0.12 & 0.08 & 0.03 & 0.05 & 0.32 & 0.03 \\
\hline $\mathrm{Al}_{2} \mathrm{O}_{3}$ & 20.82 & 20.71 & 13.80 & 19.71 & 19.63 & 18.91 & 0.12 & 20.71 & 21.21 & 20.96 & 27.56 & 21.92 & 21.48 & 21.51 & 26.24 \\
\hline $\mathrm{Cr}_{2} \mathrm{O}_{3}$ & 0.02 & 0.10 & 0.00 & 0.00 & 0.06 & 0.00 & 0.00 & 0.03 & 0.03 & 0.02 & 0.02 & 0.02 & 0.02 & 0.04 & 0.01 \\
\hline $\mathrm{FeO}^{*}$ & 26.71 & 27.06 & 10.11 & 28.48 & 21.43 & 29.03 & 26.24 & 36.15 & 27.42 & 29.95 & 7.75 & 28.61 & 35.94 & 35.16 & 6.98 \\
\hline $\mathrm{MnO}$ & 1.70 & 0.20 & 0.91 & 2.86 & 14.29 & 9.76 & 0.85 & 2.73 & 13.29 & 1.07 & 0.18 & 0.35 & 2.31 & 5.86 & 0.06 \\
\hline $\mathrm{MgO}$ & 9.06 & 9.89 & 0.06 & 0.67 & 3.39 & 1.45 & 0.05 & 2.15 & 1.56 & 2.52 & 0.07 & 8.40 & 2.24 & 1.72 & 0.01 \\
\hline $\mathrm{CaO}$ & 1.52 & 1.07 & 35.79 & 9.61 & 1.50 & 1.46 & 32.87 & 1.16 & 1.31 & 6.93 & 24.08 & 1.57 & 2.12 & 0.96 & 23.29 \\
\hline $\mathrm{Na}_{2} \mathrm{O}$ & 0.04 & 0.02 & 0.03 & 0.05 & 0.12 & 0.06 & 0.04 & 0.08 & 0.10 & 0.03 & 0.07 & 0.04 & 0.04 & 0.02 & 0.02 \\
\hline $\mathrm{K}_{2} \mathrm{O}$ & 0.02 & 0.01 & 0.02 & 0.03 & 0.00 & 0.00 & 0.02 & 0.01 & 0.01 & 0.02 & 0.01 & 0.01 & 0.00 & 0.01 & 0.03 \\
\hline Total & 100.63 & 99.40 & 99.34 & 100.23 & 98.93 & 99.22 & 92.20 & 99.67 & 102.53 & 96.41 & 98.88 & 99.51 & 100.69 & 102.04 & 94.50 \\
\hline $\mathrm{Si}$ & 3.098 & 3.091 & 3.016 & 3.082 & 3.101 & 3.138 & 2.882 & 2.982 & 2.988 & 2.900 & 2.938 & 2.997 & 2.945 & 2.927 & 2.967 \\
\hline $\mathrm{Al}$ & 1.868 & 1.872 & 1.271 & 1.851 & 1.864 & 1.814 & 0.013 & 1.992 & 1.989 & 2.058 & 2.442 & 2.008 & 2.043 & 2.035 & 2.426 \\
\hline $\mathrm{Ti}$ & 0.002 & 0.002 & 0.003 & 0.010 & 0.002 & 0.000 & 0.003 & 0.008 & 0.003 & 0.008 & 0.005 & 0.002 & 0.003 & 0.019 & 0.002 \\
\hline $\mathrm{Cr}$ & 0.001 & 0.006 & 0.000 & 0.000 & 0.004 & 0.000 & 0.000 & 0.002 & 0.002 & 0.001 & 0.001 & 0.001 & 0.001 & 0.003 & 0.000 \\
\hline $\mathrm{Fe}^{+3}$ & 0.063 & 0.060 & 0.661 & 0.085 & 0.061 & 0.092 & 1.976 & 0.011 & 0.012 & 0.002 & 0.000 & 0.000 & 0.000 & 0.000 & 0.000 \\
\hline $\mathrm{Fe}^{+2}$ & 1.637 & 1.675 & 0.000 & 1.813 & 1.382 & 1.883 & 0.000 & 2.456 & 1.812 & 2.084 & 0.487 & 1.859 & 2.425 & 2.361 & 0.458 \\
\hline $\mathrm{Mn}$ & 0.110 & 0.013 & 0.060 & 0.193 & 0.975 & 0.673 & 0.065 & 0.189 & 0.896 & 0.075 & 0.011 & 0.023 & 0.158 & 0.398 & 0.004 \\
\hline $\mathrm{Mg}$ & 1.027 & 1.130 & 0.006 & 0.079 & 0.407 & 0.176 & 0.006 & 0.261 & 0.185 & 0.313 & 0.008 & 0.973 & 0.269 & 0.205 & 0.001 \\
\hline $\mathrm{Ca}$ & 0.124 & 0.088 & 2.996 & 0.821 & 0.129 & 0.127 & 3.172 & 0.101 & 0.112 & 0.619 & 1.939 & 0.130 & 0.183 & 0.083 & 1.957 \\
\hline $\mathrm{Na}$ & 0.006 & 0.003 & 0.004 & 0.008 & 0.018 & 0.009 & 0.008 & 0.012 & 0.015 & 0.004 & 0.009 & 0.005 & 0.006 & 0.003 & 0.003 \\
\hline $\mathrm{K}$ & 0.002 & 0.001 & 0.001 & 0.003 & 0.000 & 0.000 & 0.002 & 0.001 & 0.001 & 0.002 & 0.001 & 0.001 & 0.000 & 0.001 & 0.003 \\
\hline Total & 7.938 & 7.940 & 8.018 & 7.945 & 7.942 & 7.913 & 8.126 & 8.014 & 8.015 & 8.065 & 7.841 & 8.000 & 8.033 & 8.036 & 7.821 \\
\hline $\operatorname{Prp}(\%)$ & 35.453 & 38.880 & 0.209 & 2.722 & 14.063 & 6.149 & 0.195 & 8.675 & 6.170 & 10.123 & 0.307 & 32.585 & 8.869 & 6.737 & 0.053 \\
\hline Alm (\%) & 56.492 & 57.643 & 0.000 & 62.390 & 47.772 & 65.865 & 0.000 & 81.694 & 60.298 & 67.433 & 19.937 & 62.275 & 79.911 & 77.475 & 18.917 \\
\hline Sps $(\%)$ & 3.779 & 0.445 & 1.962 & 6.636 & 33.703 & 23.528 & 2.005 & 6.274 & 29.809 & 2.431 & 0.461 & 0.772 & 5.197 & 13.070 & 0.159 \\
\hline Grs (\%) & 4.134 & 2.929 & 64.374 & 27.005 & 4.311 & 4.242 & 0.621 & 3.337 & 3.698 & 19.981 & 79.259 & 4.366 & 6.019 & 2.715 & 80.860 \\
\hline $\operatorname{Adr}(\%)$ & 0.139 & 0.093 & 33.455 & 1.246 & 0.142 & 0.216 & 97.180 & 0.018 & 0.023 & 0.022 & 0.000 & 0.000 & 0.000 & 0.000 & 0.000 \\
\hline Uvar (\%) & 0.003 & 0.010 & 0.000 & 0.000 & 0.009 & 0.000 & 0.000 & 0.003 & 0.003 & 0.010 & 0.037 & 0.003 & 0.004 & 0.004 & 0.010 \\
\hline
\end{tabular}

Table 6 (continued).

Lower Levee Complex

NA-27-3 NA-27-5 NA-27-6 NA-27-7 NA-27-8 NA-27-9 NA-27-11 NA-27-12 NA-27-14 NA-27-15 NA-30-1 NA-30-2 NA-30-3 NA-30-4 NA-30-5

\begin{tabular}{|c|c|c|c|c|c|c|c|c|c|c|c|c|c|c|c|}
\hline $\mathrm{SiO}_{2}$ & 40.52 & 37.85 & 37.03 & 38.34 & 36.86 & 35.21 & 37.21 & 38.76 & 36.28 & 38.39 & 36.05 & 36.53 & 37.10 & 36.20 & 37.11 \\
\hline $\mathrm{TiO}_{2}^{2}$ & 0.00 & 0.10 & 0.44 & 0.07 & 0.00 & 0.18 & 0.03 & 0.03 & 0.13 & 0.08 & 0.43 & 0.05 & 0.02 & 0.02 & 0.13 \\
\hline $\mathrm{Al}_{2} \mathrm{O}_{3}$ & 28.76 & 19.61 & 11.66 & 20.33 & 20.30 & 5.78 & 21.77 & 21.23 & 19.96 & 21.24 & 18.34 & 21.38 & 21.55 & 21.61 & 21.83 \\
\hline $\mathrm{Cr}_{2} \mathrm{O}_{3}$ & 0.00 & 0.04 & 0.00 & 0.08 & 0.03 & 0.00 & 0.10 & 0.00 & 0.00 & 0.03 & 0.02 & 0.04 & 0.00 & 0.00 & 0.00 \\
\hline $\mathrm{FeO}^{*}$ & 2.55 & 17.60 & 12.59 & 29.00 & 34.01 & 19.49 & 10.80 & 26.84 & 28.71 & 26.30 & 4.43 & 34.58 & 31.13 & 39.40 & 29.47 \\
\hline $\mathrm{MnO}$ & 0.20 & 8.74 & 0.36 & 1.04 & 1.73 & 0.07 & 0.13 & 0.67 & 1.33 & 0.44 & 0.22 & 2.80 & 4.47 & 0.33 & 0.22 \\
\hline $\mathrm{MgO}$ & 0.04 & 0.22 & 0.12 & 6.69 & 2.89 & 0.15 & 0.03 & 8.30 & 1.00 & 9.43 & 0.19 & 3.11 & 2.99 & 1.47 & 1.44 \\
\hline $\mathrm{CaO}$ & 22.75 & 13.95 & 34.27 & 2.26 & 1.62 & 33.54 & 23.26 & 2.43 & 9.18 & 1.52 & 35.22 & 1.24 & 3.54 & 1.80 & 10.52 \\
\hline $\mathrm{Na}_{2} \mathrm{O}$ & 1.35 & 0.09 & 0.06 & 0.08 & 0.13 & 0.04 & 0.06 & 0.06 & 0.07 & 0.09 & 0.04 & 0.04 & 0.07 & 0.03 & 0.08 \\
\hline $\mathrm{K}_{2} \mathrm{O}$ & 0.03 & 0.02 & 0.01 & 0.02 & 0.01 & 0.03 & 0.01 & 0.01 & 0.00 & 0.01 & 0.01 & 0.00 & 0.00 & 0.02 & 0.01 \\
\hline Total & 96.20 & 98.22 & 96.54 & 97.91 & 97.58 & 94.49 & 93.40 & 98.33 & 96.66 & 97.53 & 94.95 & 99.77 & 100.87 & 100.88 & 100.81 \\
\hline $\mathrm{Si}$ & 3.040 & 3.057 & 2.995 & 3.053 & 3.036 & 2.984 & 3.033 & 3.036 & 3.007 & 3.017 & 2.904 & 2.957 & 2.959 & 2.935 & 2.943 \\
\hline $\mathrm{Al}$ & 2.543 & 1.866 & 1.111 & 1.907 & 1.970 & 0.577 & 2.091 & 1.959 & 1.949 & 1.967 & 1.741 & 2.039 & 2.025 & 2.065 & 2.040 \\
\hline $\mathrm{Ti}$ & 0.000 & 0.006 & 0.027 & 0.004 & 0.000 & 0.011 & 0.002 & 0.002 & 0.008 & 0.005 & 0.026 & 0.003 & 0.001 & 0.001 & 0.008 \\
\hline $\mathrm{Cr}$ & 0.000 & 0.003 & 0.000 & 0.005 & 0.002 & 0.000 & 0.006 & 0.000 & 0.000 & 0.002 & 0.001 & 0.003 & 0.000 & 0.000 & 0.000 \\
\hline $\mathrm{Fe}^{+3}$ & 0.000 & 0.086 & 0.851 & 0.047 & 0.001 & 1.381 & 0.000 & 0.014 & 0.039 & 0.014 & 0.298 & 0.000 & 0.000 & 0.000 & 0.000 \\
\hline $\mathrm{Fe}^{+2}$ & 0.160 & 1.102 & 0.000 & 1.883 & 2.341 & 0.000 & 0.736 & 1.743 & 1.951 & 1.714 & 0.000 & 2.340 & 2.076 & 2.671 & 1.954 \\
\hline $\mathrm{Mn}$ & 0.013 & 0.598 & 0.025 & 0.070 & 0.121 & 0.005 & 0.009 & 0.044 & 0.093 & 0.029 & 0.015 & 0.192 & 0.302 & 0.023 & 0.015 \\
\hline $\mathrm{Mg}$ & 0.004 & 0.026 & 0.014 & 0.793 & 0.355 & 0.019 & 0.004 & 0.968 & 0.123 & 1.104 & 0.023 & 0.375 & 0.355 & 0.178 & 0.170 \\
\hline $\mathrm{Ca}$ & 1.828 & 1.207 & 2.968 & 0.193 & 0.143 & 3.044 & 2.030 & 0.204 & 0.815 & 0.128 & 3.038 & 0.107 & 0.302 & 0.156 & 0.893 \\
\hline $\mathrm{Na}$ & 0.196 & 0.014 & 0.009 & 0.012 & 0.021 & 0.007 & 0.009 & 0.009 & 0.011 & 0.014 & 0.006 & 0.006 & 0.011 & 0.005 & 0.012 \\
\hline $\mathrm{K}$ & 0.003 & 0.002 & 0.001 & 0.002 & 0.001 & 0.003 & 0.001 & 0.001 & 0.000 & 0.001 & 0.001 & 0.000 & 0.000 & 0.002 & 0.001 \\
\hline Total & 7.788 & 7.967 & 8.002 & 7.970 & 7.989 & 8.031 & 7.922 & 7.981 & 7.997 & 7.994 & 8.054 & 8.022 & 8.032 & 8.035 & 8.036 \\
\hline $\operatorname{Prp}(\%)$ & 0.223 & 0.902 & 0.481 & 26.993 & 11.982 & 0.617 & 0.131 & 32.714 & 4.140 & 37.110 & 0.741 & 12.439 & 11.704 & 5.865 & 5.610 \\
\hline $\operatorname{Alm}(\%)$ & 7.977 & 37.575 & 0.000 & 64.065 & 79.112 & 0.000 & 26.482 & 58.899 & 65.407 & 57.605 & 0.000 & 77.628 & 68.388 & 88.224 & 64.437 \\
\hline Sps $(\%)$ & 0.634 & 20.380 & 0.820 & 2.385 & 4.077 & 0.164 & 0.323 & 1.501 & 3.130 & 0.984 & 0.488 & 6.366 & 9.946 & 0.748 & 0.487 \\
\hline Grs (\%) & 91.166 & 39.271 & 55.886 & 6.381 & 4.822 & 29.248 & 72.839 & 6.837 & 26.791 & 4.265 & 84.268 & 3.561 & 9.962 & 5.163 & 29.466 \\
\hline $\operatorname{Adr}(\%)$ & 0.000 & 1.818 & 42.813 & 0.158 & 0.002 & 69.972 & 0.000 & 0.049 & 0.533 & 0.031 & 14.442 & 0.000 & 0.000 & 0.000 & 0.000 \\
\hline Uvar (\%) & 0.000 & 0.054 & 0.000 & 0.017 & 0.005 & 0.000 & 0.224 & 0.000 & 0.000 & 0.004 & 0.062 & 0.004 & 0.000 & 0.000 & 0.000 \\
\hline
\end{tabular}


Table 7. EMPA analyses of detrital epitdote-group minerals from the Amazon Fan.

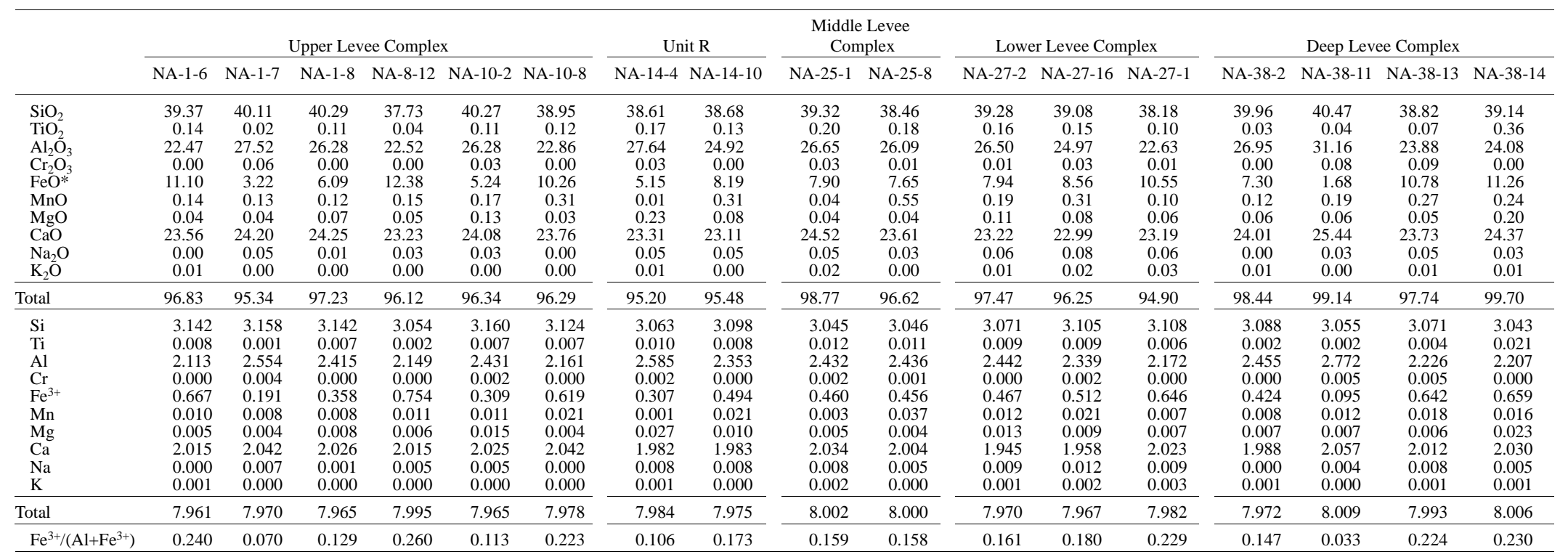

Note: $\mathrm{FeO}^{*}=$ total $\mathrm{Fe}$ as $\mathrm{FeO}$ 
A

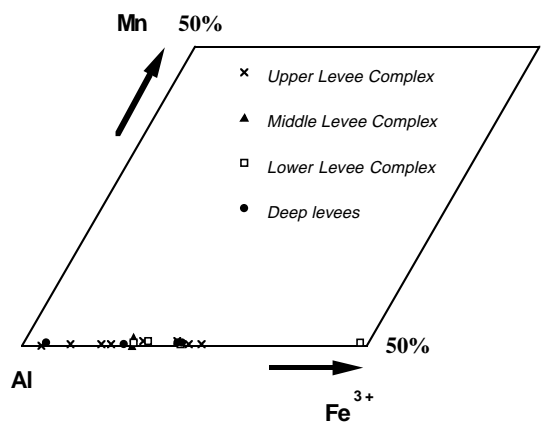

B

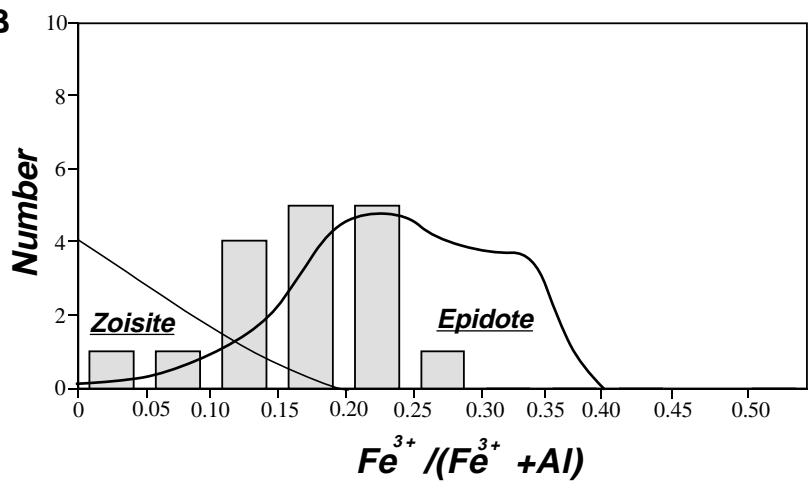

Figure 8. A. Plot of detrital epidote-group mineral compositions from the Amazon Fan. B. $\mathrm{Fe}^{3+} /\left(\mathrm{Al}+\mathrm{Fe}^{3+}\right)$ ratios in epidote-group minerals. Vertical axis shows the number of analyses. Fields after Enami and Banno (1980).

Table 8. EMPA analyses of detrital chloritoid form the Amazon Fan.

\begin{tabular}{|c|c|c|c|c|c|}
\hline & \multicolumn{3}{|c|}{ Upper Levee Complex } & \multicolumn{2}{|c|}{ Deep Levee Complex } \\
\hline & NA-1-9 & NA-10-10 & NA-10-12 & NA-38-B & NA-38-5 \\
\hline $\mathrm{SiO}_{2}$ & 25.61 & 26.29 & 24.36 & 23.90 & 24.92 \\
\hline $\mathrm{TiO}_{2}$ & 0.05 & 0.19 & 0.16 & 0.04 & 0.03 \\
\hline $\mathrm{Al}_{2} \mathrm{O}_{3}$ & 39.02 & 38.06 & 37.22 & 39.22 & 40.66 \\
\hline $\mathrm{Cr}_{2} \mathrm{O}_{3}$ & 0.07 & 0.04 & 0.06 & 0.00 & 0.00 \\
\hline $\mathrm{FeO}^{*}$ & 21.01 & 20.78 & 19.77 & 25.10 & 22.98 \\
\hline $\mathrm{MnO}$ & 0.20 & 0.56 & 0.17 & 0.06 & 0.25 \\
\hline $\mathrm{MgO}$ & 4.17 & 1.08 & 4.46 & $\begin{array}{l}1.60 \\
-60\end{array}$ & 3.13 \\
\hline $\mathrm{CaO}$ & 0.05 & 0.05 & 0.08 & 0.05 & 0.07 \\
\hline $\mathrm{Na}_{2} \mathrm{O}$ & 0.01 & 1.03 & 0.00 & 0.04 & 0.06 \\
\hline $\mathrm{K}_{2} \mathrm{O}$ & 0.01 & 0.76 & 0.01 & 0.00 & 0.02 \\
\hline Total & 90.19 & 88.83 & 86.29 & 90.00 & 92.12 \\
\hline $\mathrm{Si}$ & 2.129 & 2.234 & 2.115 & 2.038 & 2.048 \\
\hline $\mathrm{Ti}$ & 0.003 & 0.012 & 0.010 & 0.003 & 0.002 \\
\hline $\mathrm{Al}$ & 3.822 & 3.812 & 3.808 & 3.942 & 3.938 \\
\hline $\mathrm{Cr}$ & 0.004 & 0.003 & 0.004 & 0.000 & 0.000 \\
\hline $\mathrm{Fe}^{2+}$ & 1.461 & 1.477 & 1.435 & 1.791 & 1.579 \\
\hline $\mathrm{Mn}$ & 0.014 & 0.040 & 0.012 & 0.005 & 0.017 \\
\hline $\mathrm{Mg}$ & 0.517 & 0.137 & 0.578 & 0.204 & 0.383 \\
\hline $\mathrm{Ca}$ & 0.004 & 0.005 & 0.008 & 0.004 & 0.007 \\
\hline $\mathrm{Na}$ & 0.001 & 0.169 & 0.000 & 0.006 & 0.010 \\
\hline $\mathrm{K}$ & 0.001 & 0.082 & 0.001 & 0.000 & 0.002 \\
\hline Total & 7.957 & 7.972 & 7.970 & 7.991 & 7.987 \\
\hline $\mathrm{Fe}^{2+\#}$ & 0.739 & 0.91 & 0.713 & 0.898 & 0.805 \\
\hline $\mathrm{Mg} \#$ & 0.260 & 0.083 & 0.285 & 0.102 & 0.194 \\
\hline
\end{tabular}

Note: $\mathrm{FeO}^{*}=$ total $\mathrm{Fe}$ as $\mathrm{FeO}$.

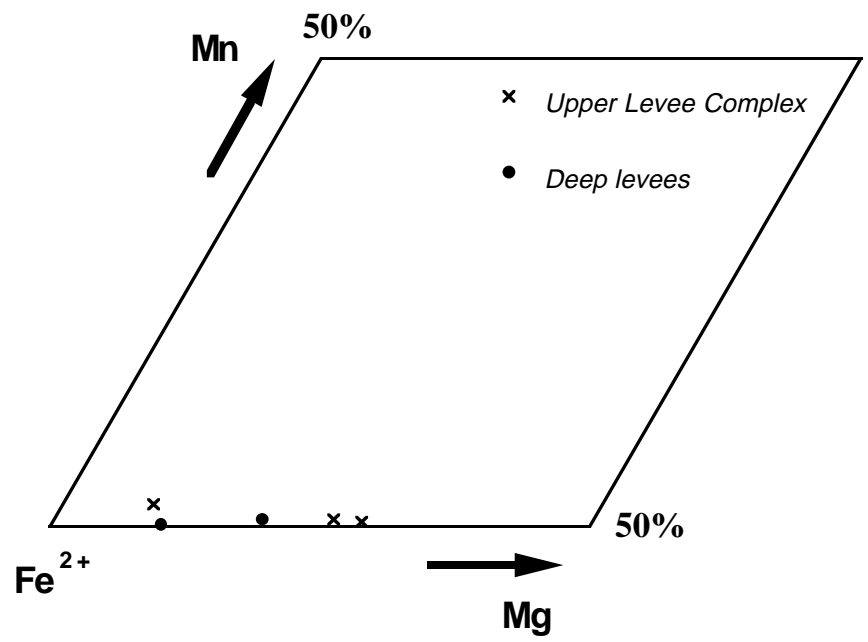

Figure 9. Plot of detrital chloritoid compositions from Amazon Fan sediments in the $\mathrm{Mn}-\mathrm{Fe}^{2+}-\mathrm{Mg}$ system. 
Table 9. EMPA analyses of detrital kyanite and staurolite from the Amazon Fan.

\begin{tabular}{|c|c|c|c|c|c|c|c|}
\hline \multirow[b]{3}{*}{ Mineral } & \multicolumn{2}{|c|}{ Upper Levee Complex } & \multirow{2}{*}{$\begin{array}{c}\begin{array}{c}\text { Lower Levee } \\
\text { Complex }\end{array} \\
\text { NA-30-1 }\end{array}$} & \multirow{2}{*}{$\begin{array}{c}\begin{array}{c}\text { Deep Lower } \\
\text { Complex }\end{array} \\
\text { NA-38-6 }\end{array}$} & \multirow[b]{3}{*}{ Mineral } & \multirow{3}{*}{$\begin{array}{c}\begin{array}{c}\text { Upper Levee } \\
\text { Complex }\end{array} \\
\text { NA-10-6 } \\
\text { Staurolite }\end{array}$} & \multirow{3}{*}{$\begin{array}{c}\begin{array}{c}\text { Middle Levee } \\
\text { Complex }\end{array} \\
\text { NA-25-4 } \\
\text { Staurolite }\end{array}$} \\
\hline & NA-8-9 & NA-8-16 & & & & & \\
\hline & Kyanite & Kyanite & Kyanite & Kyanite & & & \\
\hline $\mathrm{SiO}_{2}$ & 36.87 & 37.35 & 36.58 & 38.30 & $\mathrm{SiO}_{2}$ & 27.36 & 27.76 \\
\hline $\mathrm{TiO}_{2}$ & 0.06 & 0.01 & 0.08 & $\begin{array}{r}30.50 \\
0.05\end{array}$ & $\begin{array}{l}\mathrm{SIO}_{2} \\
\mathrm{TiO}_{2}\end{array}$ & $\begin{array}{r}27.50 \\
0.61\end{array}$ & $\begin{array}{r}21.70 \\
0.64\end{array}$ \\
\hline $\mathrm{Al}_{2} \mathrm{O}_{3}$ & 62.44 & 62.31 & 57.70 & 61.80 & $\mathrm{Al}_{2} \mathrm{O}_{3}$ & 53.76 & \\
\hline $\mathrm{Cr}_{2} \mathrm{O}_{3}$ & 0.02 & 0.03 & 0.27 & 0.00 & $\mathrm{Cr}_{2} \mathrm{O}_{3}$ & 0.01 & 0.07 \\
\hline $\mathrm{FeO}^{*}$ & 0.13 & 0.13 & 0.19 & 0.27 & $\mathrm{FeO} *$ & 11.33 & 10.99 \\
\hline $\mathrm{MnO}$ & 0.00 & 0.04 & 0.03 & 0.05 & $\mathrm{MnO}$ & 0.52 & 0.22 \\
\hline $\mathrm{MgO}$ & 0.06 & 0.00 & 0.05 & 0.05 & $\mathrm{MgO}$ & 0.99 & 1.34 \\
\hline $\mathrm{CaO}$ & 0.02 & 0.04 & 0.03 & 0.05 & $\mathrm{CaO}$ & 0.06 & 0.03 \\
\hline $\mathrm{Na}_{2} \mathrm{O}$ & 0.00 & 0.02 & 0.02 & 0.00 & $\mathrm{Na}_{2} \mathrm{O}$ & 0.00 & 0.00 \\
\hline $\mathrm{K}_{2} \mathrm{O}$ & 0.00 & 0.00 & 0.00 & 0.00 & $\mathrm{~K}_{2} \mathrm{O}$ & 0.02 & 0.00 \\
\hline Total & 99.61 & 99.92 & 94.94 & 100.57 & Total & 94.66 & \\
\hline $\mathrm{Si}$ & 3.997 & 4.034 & 4.158 & 4.109 & $\mathrm{Si}$ & 7.762 & 7.790 \\
\hline $\mathrm{Ti}$ & 0.005 & 0.001 & 0.007 & 0.004 & $\mathrm{Ti}$ & 0.131 & 0.134 \\
\hline $\mathrm{Al}$ & 7.977 & 7.933 & 7.729 & 7.815 & $\mathrm{Al}$ & 17.973 & 17.953 \\
\hline $\mathrm{Cr}$ & 0.002 & 0.003 & 0.024 & 0.000 & $\mathrm{Cr}$ & 0.002 & 0.015 \\
\hline $\mathrm{Fe}^{3+}$ & 0.011 & 0.010 & 0.016 & 0.022 & $\mathrm{Fe}^{2+}$ & 2.687 & 2.579 \\
\hline $\mathrm{Mn}$ & 0.000 & 0.003 & 0.003 & 0.004 & $\mathrm{Mn}$ & 0.126 & 0.053 \\
\hline $\mathrm{Mg}$ & 0.010 & 0.000 & 0.009 & 0.008 & $\mathrm{Mg}$ & 0.418 & 0.559 \\
\hline $\mathrm{Ca}$ & 0.002 & 0.004 & 0.003 & 0.006 & $\mathrm{Ca}$ & 0.019 & 0.010 \\
\hline $\mathrm{Na}$ & 0.000 & 0.004 & 0.004 & 0.000 & $\mathrm{Na}$ & 0.000 & 0.000 \\
\hline $\mathrm{K}$ & 0.000 & 0.000 & 0.000 & 0.001 & $\mathrm{~K}$ & 0.006 & 0.000 \\
\hline Total & 12.003 & 11.994 & 11.953 & 11.969 & Total & 29.123 & 29.092 \\
\hline $\mathrm{Fe}^{3+} /\left(\mathrm{Fe}^{3+}+\mathrm{Al}\right)$ & 0.001 & 0.001 & 0.002 & 0.003 & $\mathrm{Mg} /\left(\mathrm{Mg}+\mathrm{Fe}^{2+}\right)$ & 0.135 & 0.178 \\
\hline
\end{tabular}

Note: $\mathrm{FeO}^{*}=$ total $\mathrm{Fe}$ as $\mathrm{FeO}$

Table 10. EMPA analyses of detrital chromian spinels from the Amazon Fan.

\begin{tabular}{|c|c|c|c|c|}
\hline & \multicolumn{3}{|c|}{ Upper Levee Complex } & \multirow{2}{*}{$\begin{array}{c}\text { Middle Levee } \\
\text { Complex }\end{array}$} \\
\hline & NA-8-1 & NA-8-2 & NA-8-3 & \\
\hline $\begin{array}{l}\mathrm{Cr}_{2} \mathrm{O}_{3} \\
\mathrm{SiO}_{2} \\
\mathrm{MgO} \\
\mathrm{MnO} \\
\mathrm{Fe}_{2} \mathrm{O}_{3} \\
\mathrm{FeO} \\
\mathrm{TiO}_{2} \\
\mathrm{Al}_{2} \mathrm{O}_{3}\end{array}$ & $\begin{array}{r}31.56 \\
0.16 \\
11.72 \\
0.37 \\
6.68 \\
18.09 \\
0.36 \\
28.44 \\
\end{array}$ & $\begin{array}{r}31.23 \\
0.12 \\
11.08 \\
0.23 \\
5.32 \\
17.55 \\
0.37 \\
27.25 \\
\end{array}$ & $\begin{array}{r}34.42 \\
0.09 \\
0.44 \\
2.08 \\
7.95 \\
33.18 \\
1.25 \\
16.55 \\
\end{array}$ & $\begin{array}{r}50.30 \\
0.04 \\
11.88 \\
0.32 \\
7.27 \\
14.08 \\
0.42 \\
10.45 \\
\end{array}$ \\
\hline Total & 97.36 & 93.16 & 95.94 & 94.76 \\
\hline $\begin{array}{l}\mathrm{Ti} \\
\mathrm{Al} \\
\mathrm{Cr} \\
\mathrm{Fe}^{3+} \\
\mathrm{Fe}^{2+} \\
\mathrm{Mn} \\
\mathrm{Mg} \\
\mathrm{Si}\end{array}$ & $\begin{array}{l}0.066 \\
8.315 \\
6.190 \\
1.246 \\
3.753 \\
0.078 \\
4.333 \\
8.164 \\
\end{array}$ & $\begin{array}{l}0.071 \\
8.327 \\
6.402 \\
1.039 \\
3.807 \\
0.051 \\
4.284 \\
8.141 \\
\end{array}$ & $\begin{array}{l}0.270 \\
5.609 \\
7.827 \\
1.720 \\
7.981 \\
0.507 \\
0.188 \\
8.675 \\
\end{array}$ & $\begin{array}{r}0.086 \\
3.375 \\
10.895 \\
1.500 \\
3.227 \\
0.074 \\
4.851 \\
8.152 \\
\end{array}$ \\
\hline Total & 23.981 & 23.980 & 24.101 & 24.008 \\
\hline $\begin{array}{l}\mathrm{Cr} \# \\
\mathrm{Mg} \#\end{array}$ & $\begin{array}{l}0.427 \\
0.536\end{array}$ & $\begin{array}{l}0.435 \\
0.530\end{array}$ & $\begin{array}{l}0.583 \\
0.023\end{array}$ & $\begin{array}{l}0.764 \\
0.601\end{array}$ \\
\hline
\end{tabular}

Notes: $\mathrm{Cr} \#=\mathrm{Cr} /(\mathrm{Cr}+\mathrm{Al}) ; \mathrm{Mg} \#=\mathrm{Mg} /\left(\mathrm{Mg}+\mathrm{Fe}^{2+}\right)$. 
A

$\mathrm{Cr}$

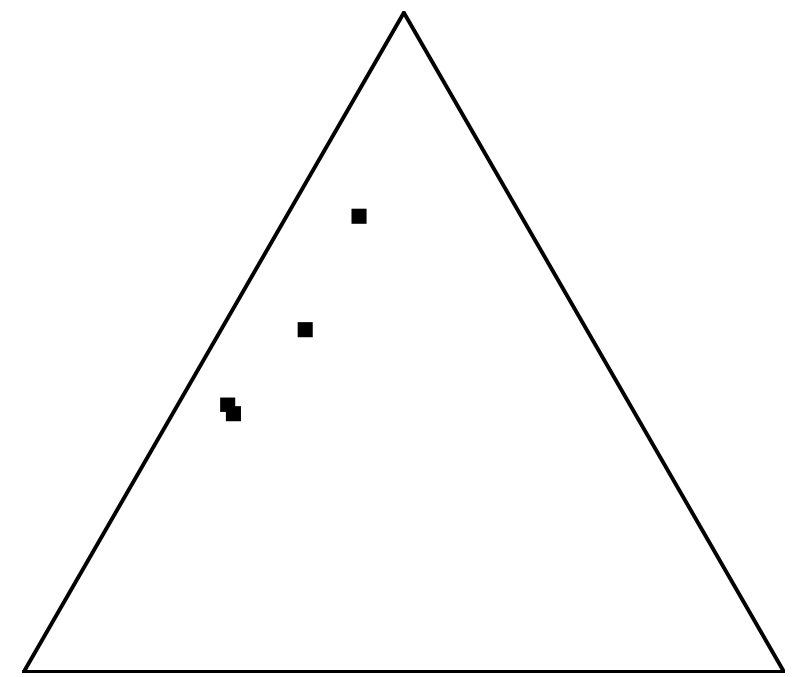

B

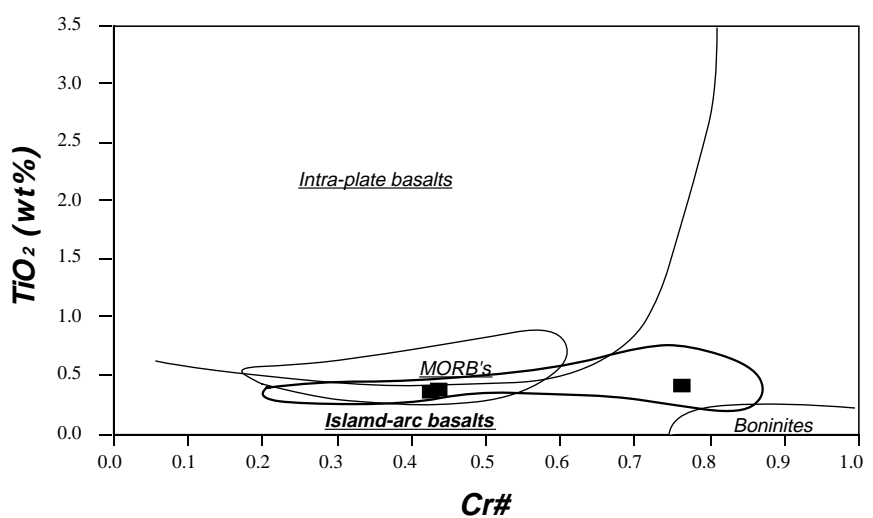

Al

$\mathrm{Fe}^{3+}$

Figure 10. A. Cr-Al-Fe ${ }^{3+}$ diagram of detrital chromian spinels from Amazon Fan sediments. $\mathbf{B}$. $\mathrm{TiO}_{2}(\mathrm{wt} \%)$ vs. $\mathrm{Cr} \#(=\mathrm{Cr} /[\mathrm{Cr}+\mathrm{Al}])$ of the detrital chromian spinels from volcanic rocks. The three magma fields encircled with solid lines are after Arai (1990). These fields apply to volcanic spinels: $\mathrm{Fe}^{3+} /\left(\mathrm{Cr}+\mathrm{Al}+\mathrm{Fe}^{3+}\right)$ $<0.2$.

Table 11. EMPA analyses of iron-oxide minerals from the Amazon Fan.

\begin{tabular}{|c|c|c|c|c|c|c|c|}
\hline \multirow[b]{3}{*}{ Mineral } & \multicolumn{3}{|c|}{ Upper Levee Complex } & \multicolumn{2}{|c|}{$\begin{array}{c}\text { Lower Levee } \\
\text { Complex }\end{array}$} & \multicolumn{2}{|c|}{ Deep Levee Complex } \\
\hline & NA-10-1 & NA-10-C & NA-10-4 & NA-27-X & NA-30-8 & NA-38-A & NA-46-1 \\
\hline & Ilmenite & Hematite & Titanite & Ilmenite & Ilmenite & Ilmenite & Hematite \\
\hline $\mathrm{SiO}_{2}$ & 0.02 & 0.11 & 30.19 & 0.12 & 0.12 & 0.08 & 0.01 \\
\hline $\mathrm{TiO}_{2}$ & 42.47 & 6.64 & 36.44 & 10.28 & 63.60 & 50.61 & 0.13 \\
\hline $\mathrm{Al}_{2} \mathrm{O}_{3}$ & 0.53 & 1.83 & 3.15 & 1.43 & 0.12 & 0.16 & 0.16 \\
\hline $\mathrm{Cr}_{2} \mathrm{O}_{3}$ & 0.05 & 0.04 & 0.33 & 0.13 & 0.06 & 0.13 & 0.01 \\
\hline $\mathrm{FeO}^{*}$ & 51.47 & 79.71 & 0.26 & 71.50 & 33.94 & 37.40 & 86.05 \\
\hline $\mathrm{MnO}$ & 0.32 & 0.34 & 0.05 & 0.14 & 0.66 & 1.58 & 0.00 \\
\hline $\mathrm{MgO}$ & 3.45 & 1.61 & 0.04 & 1.24 & 0.20 & 5.70 & 0.04 \\
\hline $\mathrm{CaO}$ & 0.12 & 0.15 & 29.33 & 0.05 & 0.18 & 0.51 & 0.09 \\
\hline $\mathrm{Na}_{2} \mathrm{O}$ & 0.04 & 0.05 & 0.06 & 0.07 & 0.03 & 0.07 & 0.09 \\
\hline $\mathrm{K}_{2} \mathrm{O}$ & 0.01 & 0.01 & 0.01 & 0.01 & 0.01 & 0.01 & 0.02 \\
\hline Total & 98.47 & 90.48 & 99.85 & 84.97 & 98.91 & 96.25 & 86.59 \\
\hline $\mathrm{Si}$ & 0.001 & 0.008 & 3.916 & 0.009 & 0.005 & 0.004 & 0.001 \\
\hline $\mathrm{Ti}$ & 1.688 & 0.361 & 0.255 & 0.578 & 2.284 & 1.928 & 0.008 \\
\hline $\mathrm{Al}$ & 0.033 & 0.156 & 0.041 & 0.126 & 0.007 & 0.010 & 0.015 \\
\hline $\mathrm{Cr}$ & 0.002 & 0.002 & 0.022 & 0.008 & 0.002 & 0.005 & 0.000 \\
\hline $\mathrm{Fe}^{2+}$ & 2.274 & 4.816 & 0.004 & 4.469 & 1.355 & 1.584 & 5.938 \\
\hline $\mathrm{Mn}$ & 0.014 & 0.021 & 0.004 & 0.009 & 0.027 & 0.068 & 0.000 \\
\hline $\mathrm{Mg}$ & 0.272 & 0.173 & 4.700 & 0.138 & 0.014 & 0.430 & 0.005 \\
\hline $\mathrm{Ca}$ & 0.007 & 0.011 & 0.007 & 0.004 & 0.009 & 0.028 & 0.008 \\
\hline $\mathrm{Na}$ & 0.004 & 0.006 & 0.001 & 0.010 & 0.003 & 0.007 & 0.015 \\
\hline $\mathrm{K}$ & 0.001 & 0.001 & 13.692 & 0.001 & 0.001 & 0.001 & 0.002 \\
\hline Total & 4.296 & 5.556 & 22.643 & 5.352 & 3.707 & 4.064 & 5.992 \\
\hline
\end{tabular}

Note: $\mathrm{FeO} *=$ total $\mathrm{Fe}$ as $\mathrm{FeO}$. 


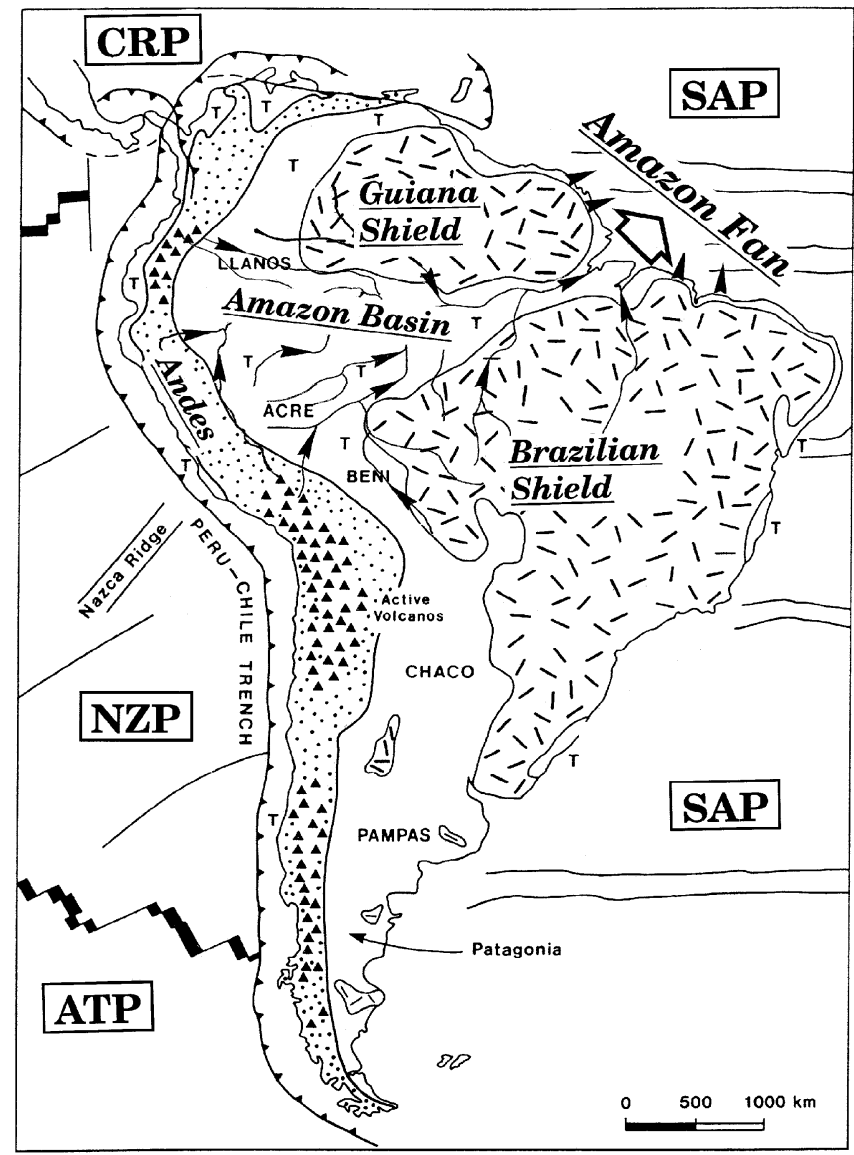

Figure 11. The general subdivisions and tectonic settings in the South American continent and Amazon River, which flows from the Andean Cordillera in the west to the Atlantic Ocean in the east. The Amazon drainage is composed mainly of volcanic and plutonic rocks (Andes; Mesozoic to modern) upstream; marine and nonmarine deposits in the Amazon Basin (PaleozoicTertiary); and Precambrian shields (Guiana and Brazilian Shields; glanulites, migmatites, amphibolites, granitoids, and quartzites) downstream. After Franzinelli and Potter (1983). T $=$ Tertiary molasse; SAP $=$ South American Plate CRP = Caribbean Plate NZP = Nazca Plate; ATP = Antarctic Plate.

Table 12. Five mineral assemblages of the Amazon Fan sediments.

\begin{tabular}{|c|c|c|}
\hline Group & Assemblage & Inferred source rocks \\
\hline M-group & $\begin{array}{l}\text { Quartz (angular-type) + zircon (euhedral-type) + } \\
\text { Mica group + hornblende }(\text { green-type })+\text { feldspar } \\
\text { (K-feldspar + plagioclase }+ \text { kyanite + silimanite? } \\
+ \text { chloritoid + garnet (almandine } ~ \text { pyrope })+ \\
\text { staurolite + Epidote group + ilmenite + titanite + } \\
\text { hematite? + Mica schist + rutile + tourmaline + } \\
\text { apatite }\end{array}$ & $\begin{array}{l}\text { Regional metamorphic rocks } \\
\text { (mP-type: Epidote-Amphibolite Facies- } \\
\text { Amphibolite Facies-Granulite Facies) }\end{array}$ \\
\hline $\mathrm{M}^{*}$-group & Garnet (high grossular) + rutile & $\begin{array}{l}\text { Regional metamorphic rocks } \\
\text { (hP-type: Eclogite Facies?) }\end{array}$ \\
\hline P-group & $\begin{array}{l}\text { Quartz (angular-type) + zircon (euhedral-type) + } \\
\text { Mica group + hornblende }(\text { green-type) + K-feldspar } \\
+ \text { plagioclase + ilmenite + titanite + hematite? + } \\
\text { plutonic rock fragments + rutile + tourmaline + } \\
\text { zircon }\end{array}$ & Regional plutonic rocks \\
\hline V-group & $\begin{array}{l}\text { Augite }+ \text { hypersthene }+ \text { hornblende (brown-type) }+ \\
\text { chromian spinel (high Ti-type) }+ \text { ilmenite }+ \\
\text { volcanic rock fragments (volcanic glass, dacite, } \\
\text { basalt } \sim \text { andesite }+ \text { apatite }\end{array}$ & Arc volcanic rocks \\
\hline S-group & $\begin{array}{l}\text { Quartzite + quartz (round-type) + zircon (round- } \\
\text { type) + rutile (round-type)? + turmaline (round- } \\
\text { type) + hematite? + apatite }\end{array}$ & Recycled sediments \\
\hline
\end{tabular}

